International Journal of Modern Anthropology

Int. J. Mod. Anthrop. 2020. Vol. 2, Issue 14, pp. $237-.273$

DOI: http://dx.doi.org/10.4314/ijma.v2i14.2

Available online at: www.ata.org.tn \& https: //www.ajol.info/index.php/ijma

Research Report

\title{
Intramural Burials from the Ancient Byzantine Settlement in Khirbet es-Samrā in Jordan
}

\author{
Abdalla J. Nabulsi ${ }^{1}$ *, Petra Schönrock-Nabulsi ${ }^{2}$, Jean-Baptiste Humbert ${ }^{3}$, Alain \\ Desreumaux ${ }^{4}$, Christina Wurst ${ }^{5}$ \\ ${ }^{1-}$ Universität Hamburg, Germany. ${ }^{2-}$ Bad Zwischenahn, Germany. ${ }^{3-}$ Ecole Biblique et Archéologique Française de \\ Jérusalem. ${ }^{4-}$ C.N.R.S, Paris, France. ${ }^{5-}$ Eurac Research Institute for Mummy Studies, Bolzano, Italy. \\ * Corresponding author.E mail:fbga023@uni-hamburg.de
}

(Received 7 October 2020; Accepted 23 October 2020; Published 20 November 2020)

Abstract - The church burials of Room-94 and Church-79 as well as the Tower 35Tomb were excavated within the ancient Byzantine settlement in Khirbet es-Samrā, North Jordan. They were initially dated between the $7^{\text {th }}$ and $9^{\text {th }}$ centuries AD. The report provides the results of macroscopic analyses of the obtained human skeletal remains. These include demographic, anthropometric, epigenetic, and pathologic features. The available biological and archaeological evidence tend to suggest that the five adults and child buried in Room-94 tomb were related males, possibly of one local and highly positioned family that was associated with the adjacent Church 95. The six were successively buried in the "private" tomb in Room-94 of Church-95 and not in the "public" cemetery just outside the settlement. The two probable cases of brucellar lesions on the cervical vertebrae of two adults could be indicative of an animal breeding family and that dairy products were part of the local diet. The report also suggests a possible relatedness between Room-94 tomb burials and the $7^{\text {th }}$ century AD senile female burial in Church-79, which was previously assumed to be a male churchfunctionary burial. Despite being marked by a cross-engraved stone and a probably lethal arrow injury, the available evidence lead to conclude that the male Tower burial, previously identified as of the $9^{\text {th }}$ century $\mathrm{AD}$, was in fact a medieval burial and that it is neither related to the ancient settlement nor to its ancient population. Also presented are some rarely reported biological features, e.g. the "en bloc" manifestation of the transverse foramen division on the cervical vertebrae $\mathrm{C} 5$ to $\mathrm{C} 7$.

Keywords: Jordan - Byzantine Period - Church Burial - Anthropometry - EpigeneticsPaleopathology. 


\section{Introduction}

The ancient Khirbet es-Samrā settlement in north Jordan evolved from a Nabataean trade station to a "Roman fortress" then flourished to a small settlement (Haditha) during the late Roman and the Byzantine era $\left(4^{\text {th }}\right.$ to $7^{\text {th }}$ century $\left.\mathrm{AD}\right)$ before being abandoned at the beginning of the $9^{\text {th }}$ century AD (Humbert 1998). Excavations at the site were carried out since the late 1970's by the French team from the École Biblique. These lead to the discovery of 11 churches, dated between the $6^{\text {th }}$ and $8^{\text {th }}$ century AD and with more or less preserved mosaic floors, beside other buildings inside the settlement (Humbert 2010). During these excavations a number of human burials were discovered in tombs within the ruins of the ancient settlement.

The Byzantine period saw the return of intramural burials, particularly in and around churches that were largely associated with Christian saints and martyrs' cult practices (Margalit 1990, Kazhdan et al. 1991, Tritsaroli and Valentin 2008), as well as for church building donors and their families (Constas 2006). In the Near East, the practice was restricted to single or few church burials as in Syria, Lebanon, Palestine, and Egypt (e.g. Margalit 1990, Parker 1999, Goldfus 2006, Aravecchia et al. 2015). In Jordan, many Byzantine intramural and church burials were reported, among others, from Amman (Zayadine 1985), Jerash and Mount Nebo (Piccirillo 1989), Umm er Rasas (Piccirillo 1991, Humayma (Schick 1995), Yajuz (Khalil 1998), 'Ain Abata (Politis 2010) and the Jordan Valley (Nabulsi 2011).

Between 1987 and 1993 three tombs were excavated within the ancient settlement of Khirbet es-Samrā ${ }^{1}$. Two were discovered in side-rooms attached to Church-79 and Church-95 and one within the "Roman" fort (Fig. 1). This report provides a short archaeological description of the three burial sites and the results of the osteological analyses carried out on the retrieved human skeletal remains from these tombs. Depending on the available material of each skeleton, the report provides information on the observed metric and non-metric (epigenetic) variables as well as description of the pathological conditions, particularly in cases of special interest. The study discusses the possible "biological" relationship(s) between the buried, based on the available biological variables as well as the archaeological evidence and will attempt to explain intramural burials in a site where a large cemetery is less than a 100 meters to the East of the settlement.

\footnotetext{
${ }^{1}$ A few more burials discovered since 2002 were mostly of recent date and are not available for analyses.
} 


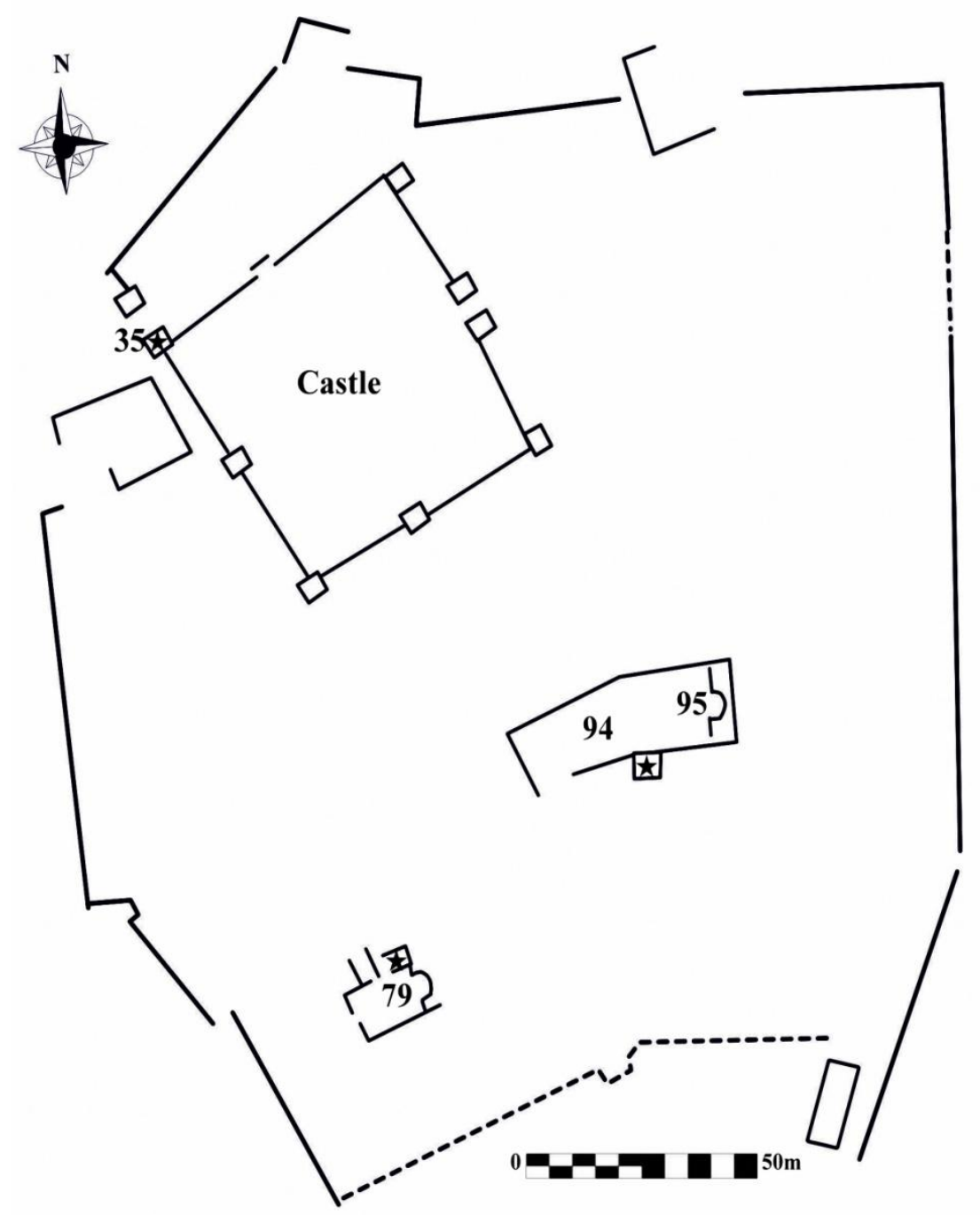

Fig. 1 The location of the three excavated tombs in Khirbet es-Samrā ancient settlement (based on drawing by Humbert 1998, Fig. 16).

When otherwise not stated, all drawings and pictures in this report are provided by the first two authors.

\section{A- Room-94 Tomb}

During the 1986 excavation season, a built tomb dated to the second half of the $7^{\text {th }}$ century AD was discovered ca. $80 \mathrm{~cm}$ below the cleared floor of Room 94 opposing the nave of Church-95 (Humbert 1998). The closed tomb, 2x1 x0.8 $\mathrm{m}$ in size, was built in two rows of partly plastered limestone and basalt cut-stones on the whitish virgin soil layer. The tomb was closed by seven covering slabs of roughly cut rectangular limestone boulders, each ca. $100 \times 30 \times 20 \mathrm{~cm}$. Inside, the skeletal remains of six individuals, identified by the 6 skulls at its western end, were found buried in a stretched West-East position, apparently consecutively one on top or beside the other while maintaining the heads visible (Fig. 2). The human remains smelt strongly 
perfumed and are mostly of red-brown colour as a result of the excessive use of perfumed liquid substances to anoint the deceased, previous and incoming. Many of the pottery and glass vessels used for this purpose were probably those found deposited in the tomb, between the bones. Patches of cloth or their imprints are on most skulls, thus indicating that the deceased were buried wrapped in cloth shrouds (Fig. 2C).

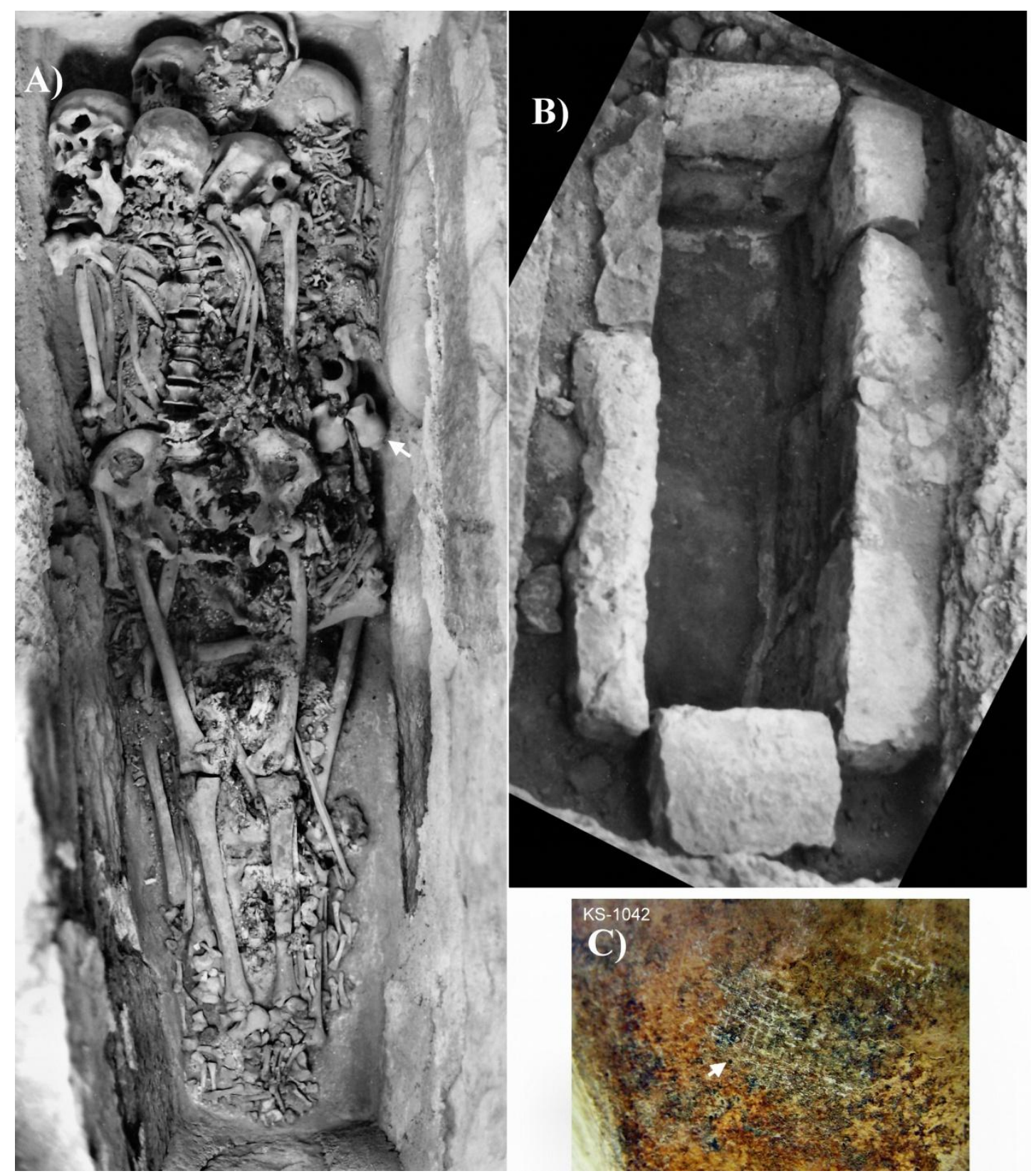

Fig. 2 Room-94 tomb:

A) After being opened and cleaned around the skeletons. The arrow marks the deposited small vessels. B) The empty excavated tomb. C: traces of cloth on the skull of KS-1042. (A and B are joint-edited from originals provided by J.-B. Humbert). 
The retrieved skeletal remains are largely intact but relatively fragile and partly mixed. Fragility led to fragmentation, particularly of the skulls and flat bones, while small bones, or fragments of them, were irretrievably deteriorated. Bones retrieved from the tomb's lower layer were more damaged, possibly due to the weight of the ensuing burials. The allocation of the mixed post-cranial parts to the six skulls (Fig. 3), numbered I to VI by the excavators, was concluded after two successively identical attempts. The bones, prepared and examined in Khirbet es-Samrā field laboratory, were brushed clean and, if necessary and possible, reconstructed using diluted water-soluble commercial wood-lime. Standard techniques based on cranial, dental, and pelvic features were applied to determine the sex and estimate age at death of each individual (Lovejoy 1985, Sjøvold 1988, Szilvássy 1998, Al Qahtani et al. 2010). The osteometrics were carried out according to the revised Martin-Saller's measurements (Bräuer 1988) and stature was estimated as in Rösing (1988). A number of cranial and post-cranial anatomic (epigenetic) variants were also documented (a. o. Hauser and de Stefano 1989, Berry and Berry 1967, Fennigan1978, Brossman et al. 2001). The different diagnostic methodologies applied in pathological analyses are cited where relevant.
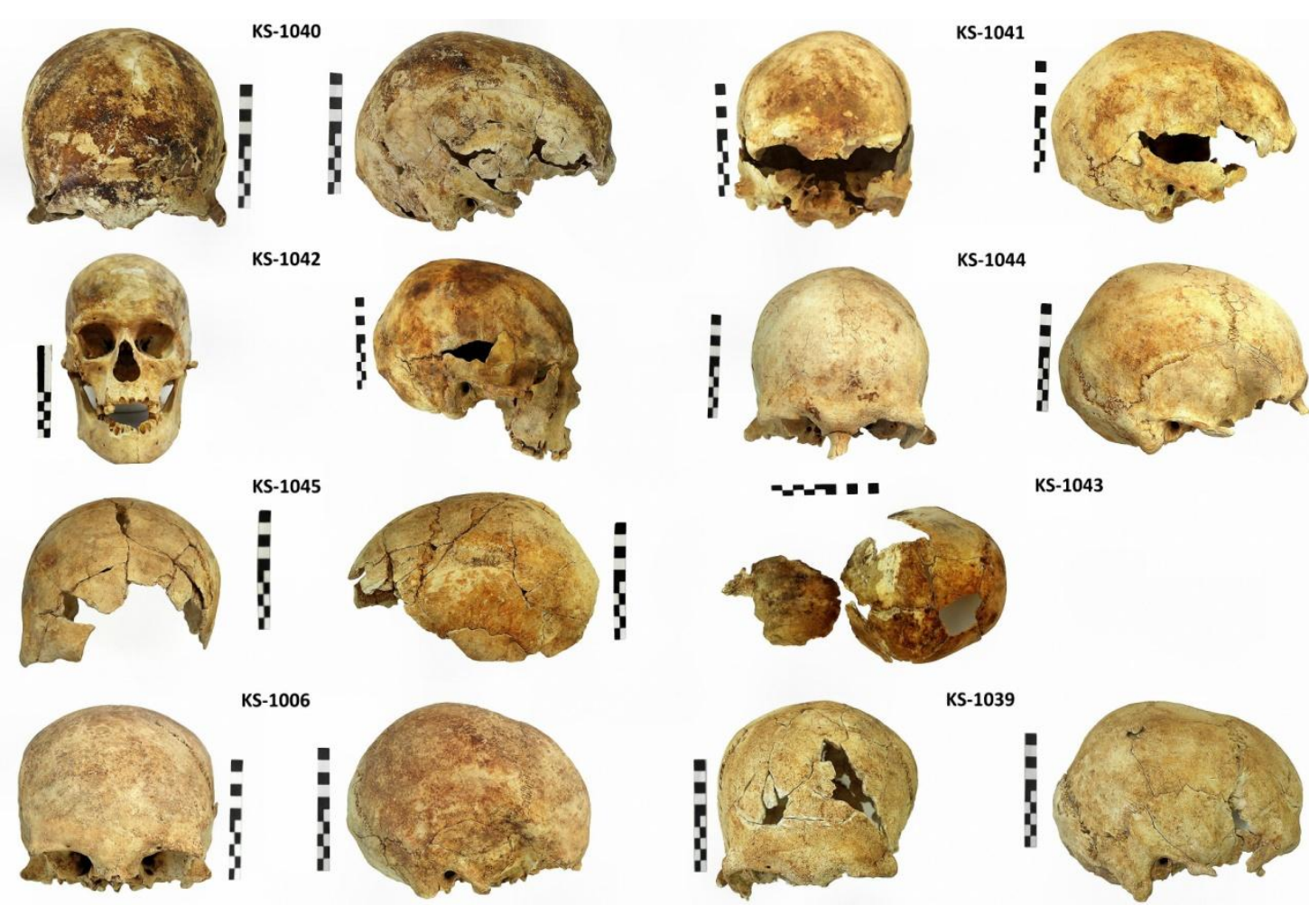

KS-1044
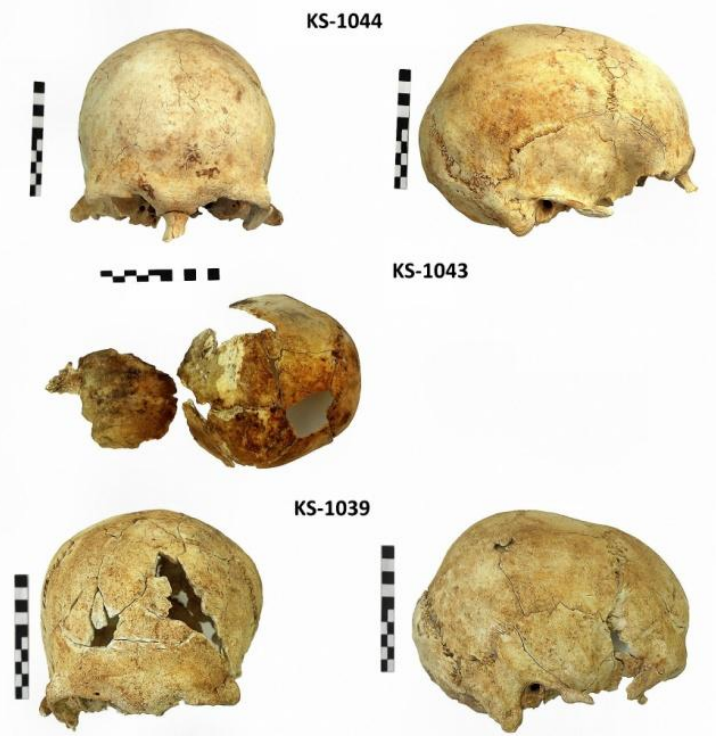

Fig. 3 Frontal and side views of the skulls from the 8 skeletons of this study. 


\section{Individual-I (KS-1040)}

The bone material allocated to this individual (laboratory no. KS-1040) represents about $85 \%$ of the whole skeleton. It reveals strong masculine features, e. g. the length of the mastoid process and an ischio-pubic index of $87.4 \%$. Obliteration of the cranial sutures, teeth wear, and the pubic symphyses surfaces suggest an age at death of 50-60 years. The osteometric measurements indicate a dolichocephalic (elongated) skull, gracile post-cranial bones, and an estimated stature of about $177 \mathrm{~cm}$ (Table 1). In addition to the epigenetic variants listed in Table 2 , there is no tubercle on the $10^{\text {th }}$ right rib (the corresponding side is missing); a bilateral fusion of the articulation surfaces between the talus and calcaneus to a single facet instead of three on each bone (Fig. 4C; comp. Bunning 1964, Anjaneyulu et al. 2014), and a $4^{\text {th }}$ left brachymetatarsal.

The cranium reveals no cribra cranii. The light porosity on the outer table of the occipital bone had probably resulted from a local infection of the overlying soft tissue, possibly caused by head lice (comp. Capasso 2007) that were wide spread in former times (Roberts and Manchester 1995, Buikstra 2010). The intact left orbit reveals a healed cribra orbitalia. At least 7 teeth were lost pre-mortem. The remaining teeth show medium strong dental abrasion, calculus, gingivitis, with parodontitis, and periodontosis on both jaws. One of the multiple apical abscesses on the root of the $1^{\text {st }}$ upper right molar (M1) perforated the base of the right maxillary sinus without causing an inflammation. Also, the temporo-mandibular joints show advanced degenerative alterations (DA).

The DA (modified classification of Schultz 1988) of the vertebral column are medium on average and consistent with the estimated age at death. There is a severe spondylosis between the cervical C3/4, C5/6 and the lumbar L3/4, strong spondylarthrosis at the left side of C6/7, Th3/4, Th4/5 and L4/5, and the right side of L2/3 and L4/5, medium sized Schmorl's nodes at the lower plates of Th9, Th11, L1 and L2 and the upper plate of L2 and L3, as well as increasing ossification of the ligamentum flavum from Th2 to Th11. There is a marked spondyloarthropathy at the left inferior facet of C6, which is perforated and the backside of the articular process inferior sinister reveals coarse porosity, indicative of an inflammatory process. The DA are bilaterally strong on the sterno- and acromio-clavicular joints and medium at the sacroiliacal, hip and retropatellar joints. Gonarthrosisis mild, but the degenerative changes at the left knee are consistent with a meniscopathy. Osteochondrosis dissecans 
is manifested at the left incisura trochlearis ulnae while the right one reveals a small dimple as a sign of a circumscribed damage of the cartilage. A similar lesion is found at the border between the facies articularis inferior and malleoli of the right tibia, which could have resulted from twisting the ankle. Both hands display unusual pronounced DA with eburnations between os pisiforme and os triquetrum as well as between the left navicular and trapezoid, possibly occupational stress related. The DA of the small joints of the digits are mild to medium and only the distal interphalangeal joints are stronger as in Heberden's arthritis (comp. McGongle et al. 2008).

On the left foot, the caput of the $1^{\text {st }}$ metatarsal, the base of the $1^{\text {st }}$ phalanx proximalis, the $2^{\text {nd }}$ cuneiforme, and the base of the $2^{\text {nd }}$ metatarsal reveal scooped-out defects (Fig. 5), which are typical gout lesions (comp. Roberts and Manchester 1995, Rothschild and Martin 2006, Waldrun 2009, Minozzi et al. 2013). There are strong DA on the left foot's $2^{\text {nd }}, 4^{\text {th }}$ and $5^{\text {th }}$ tarso-metatarsal joints and the $1^{\text {st }}$ distal interphalangeal joint. The right foot reveals minor alterations. The diaphysis of the left distal $1^{\text {st }}$ phalanx exhibits a perforating defect with minor sclerosis and fine porosity around it, probably as a result of a perforating trauma with secondary inflammation. The Th11 and Th12 are slightly wedge-shaped but with no sign of osteoporosis so that trauma was most likely the cause of this deformation. There is an interarticular spondylolysis on left side of L5's vertebral arch (Fig. 7A). Spondylolysis is a genetically predisposed anatomical condition, of 3-6.5\% frequency, that leads to stress fracture (Standaert and Herring 2000, Young and Koning 2003, Sakai et al. 2010, Leone et al. 2011, Cai et al. 2015).

Enthesopathies are bilaterally manifested at the humeral trochanter minor, the pelvic spina iliaca and tuber ischiadicum, femoral fossa trochanterica, the patella's ventral side, the insertion of Achilles' tendon of the calcaneus, as well as on the right tuberositas tibiae and both fibular ends.
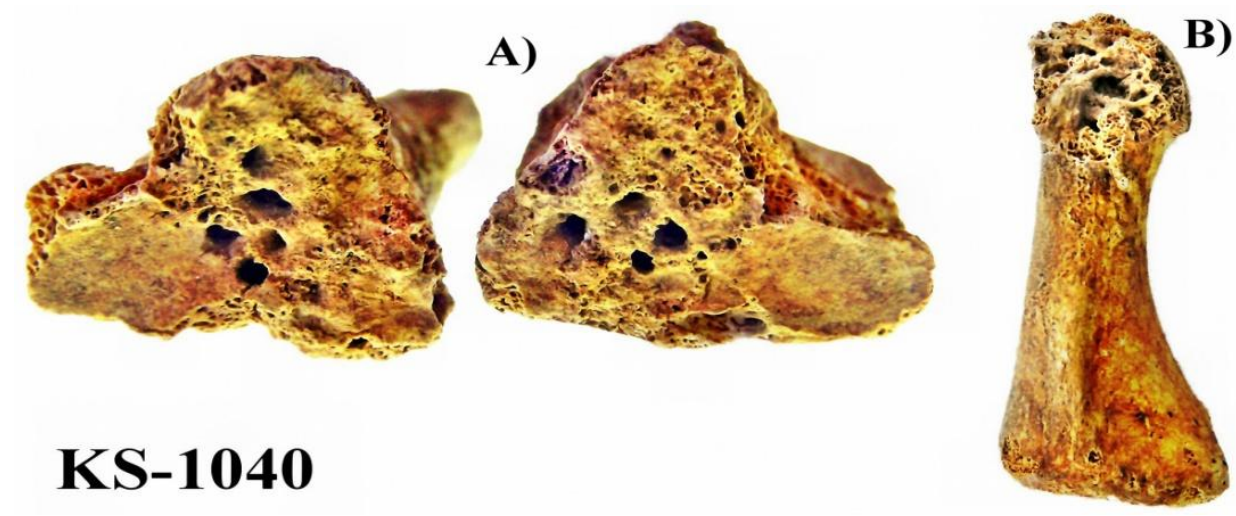

Fig. 5 Manifestation of gout at the left metatarsal 2 and os cuneiforme 2 (A) and the caput of the left $1^{\text {st }}$ metatarsal (B) of Individual-I of Room-94 tomb (unscaled). 

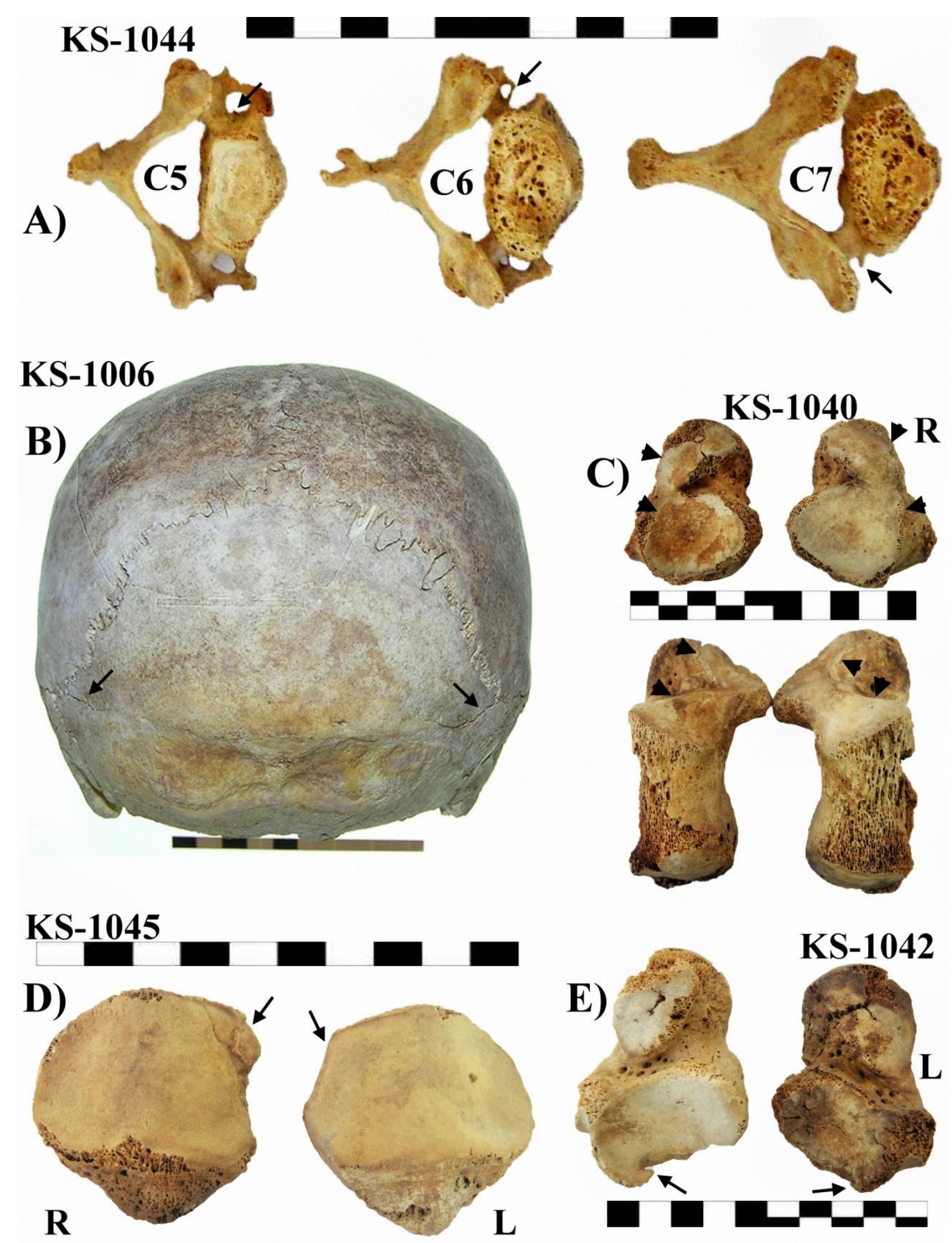

Fig. 4 Some of the epigenetic (anatomic) variants observed among the examined skeletons (pointed arrows):

A) Transverse foramen division (FT) on cervical C5 to C7 vertebrae; B) Bilateral Mendosa Suture; C) Fused articulation surfaces of the talus and calcaneus (arrows); D) Patella Bipartite (R) and bilateral Vastus Notch (L); E) Bilateral Stieda's Process of the talus. 

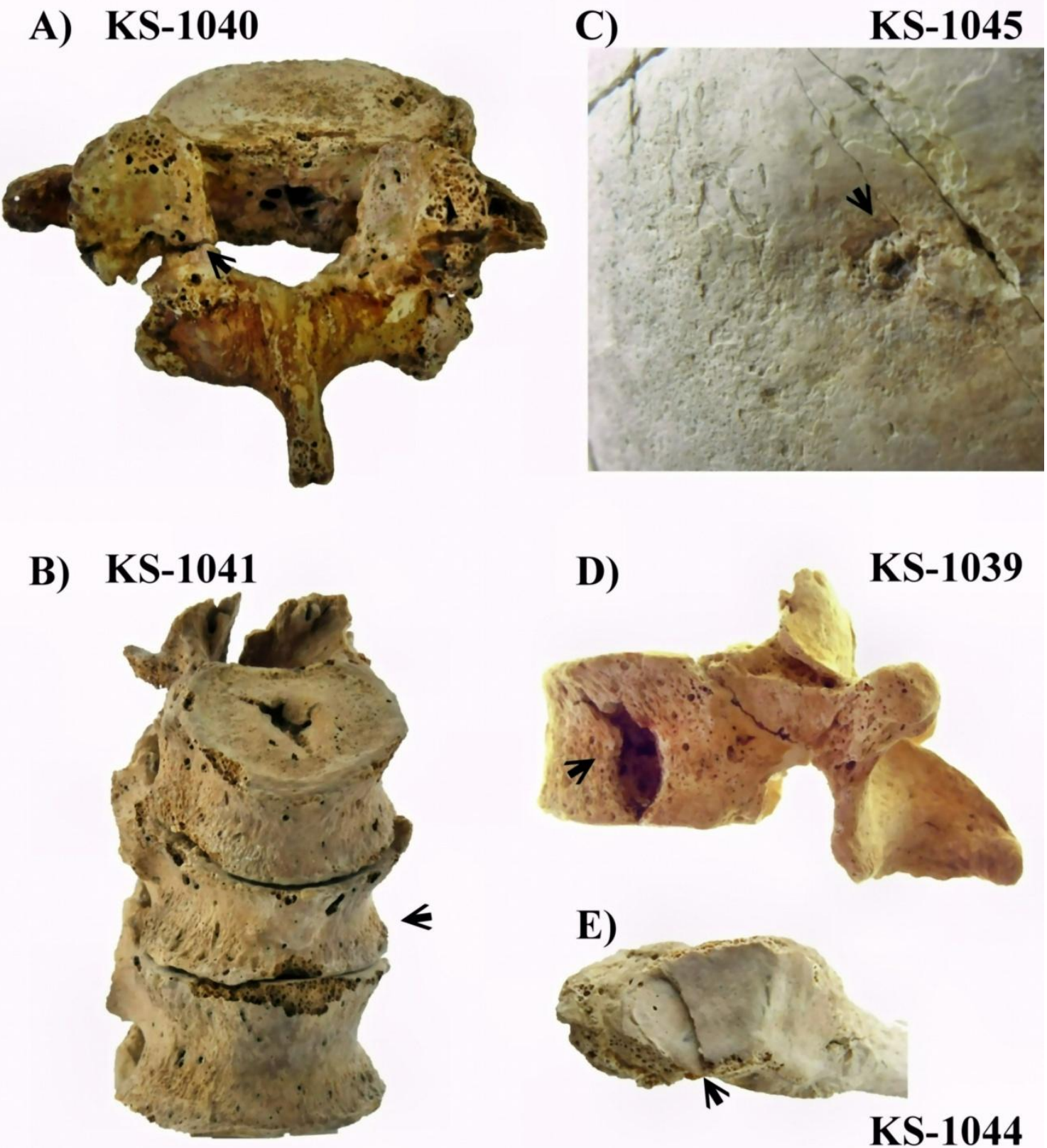

\section{KS-1044}

Fig. 7 Examples of observed traumatic injuries (arrows):

A) the interarticular spondylolysis on left side of the L5's vertebral arch of KS-1040;

B) compression fracture of the thoracic Th11 and Th12 of KS-1041;

C) injury on KS-1045's right frontal bone; D) arrowhead injury on the left side of Th11 in KS-1039;

E) intra-articular fracture on the base of KS-1044's right $5^{\text {th }}$ metatarsal. 
Table 1. The main osteometric measurements (in $\mathrm{mm}$ ) of the seven adult skeletons according to Bräuer's (1988)

modified measurements, indices, and numbering. Ht: height; I.: index; ln: length; br.: breadth; max.: maximum; $\varnothing$ : diameter. All post-cranial measurements are of the left side, otherwise stated as R. The non-adjusted stature estimations are based on the left femur length (F1) and only KS-1044 on humeral H1 (Rösing 1988).

\begin{tabular}{|c|c|c|c|c|c|c|c|}
\hline \multirow[t]{2}{*}{ Tomb } & \multicolumn{5}{|c|}{ Church 94} & \multirow{2}{*}{$\begin{array}{c}\text { Ch-79 } \\
\text { KS-1006 }\end{array}$} & \multirow{2}{*}{$\begin{array}{c}\text { Tower } \\
\text { KS-1039 }\end{array}$} \\
\hline & KS-1040 & KS-1042 & KS-1044 & KS-1041 & KS-1045 & & \\
\hline (1) g-op & 182 & 188 & 190 & 184 & 178 & 169 & 187 \\
\hline (2) $g-i$ & 181 & 180 & 184 & 179 & & 164 & 174 \\
\hline (5) n-ba & & 106 & 100 & 98 & & 96 & \\
\hline (8) eu-eu & 134 & 137 & 130 & 129 & 134 & 137 & 143 \\
\hline (9) $\mathrm{ft}-\mathrm{ft}$ & 95 & 93 & 95 & 96 & & 97 & 91 \\
\hline (11) au-au & 118 & 127 & 121 & 122 & & 116 & \\
\hline (12) ast-ast & 105 & 112 & 107 & 103 & 104 & 113 & 103 \\
\hline (43) fmt-fmt & 100 & 101 & 100 & & & 101 & \\
\hline (45) zy-zy & 125 & 137 & & & & 126 & \\
\hline (69) id-gn & 35 & 37 & 30 & 31 & 33 & 22 & 32 \\
\hline (70a) Ramus ht. & & & 68 & 61 & 70 & 58 & 69 \\
\hline (1) Cephalic I. & 73.63 & 72.87 & 68.42 & 70.11 & 75.28 & 81.07 & 76.47 \\
\hline (2) Vertical I. & & 73.94 & 67.89 & 70.11 & & 72.19 & \\
\hline (13) Transverse I. & 70.90 & 67.88 & 73.08 & 74.42 & & 70.80 & 63.64 \\
\hline (2) Hum ln. & $331 \mathrm{R}$ & & 313 & $308 \mathrm{R}$ & 312 & & \\
\hline (5) Hum max. Ø & 25 & 22 & 22 & $25 \mathrm{R}$ & 20 & 24 & 26 \\
\hline (10) Hum head $\varnothing$ & $47 \mathrm{R}$ & 43 & 44 & 46 & 45 & & 50 \\
\hline (2) $\operatorname{Rad} \ln$. & 247 & 224 & 222 & 226 & $235 \mathrm{R}$ & $219 \mathrm{R}$ & 208 \\
\hline (4) Rad max. $\varnothing$ & 17 & 16 & 15 & 15 & 15 & 16 & 18 \\
\hline (2) Ulna ln. & 247 & 225 & 220 & 238 & & $223 \mathrm{R}$ & 209 \\
\hline (11) Ulna max $\varnothing$ & 17 & 16 & 18 & 16 & 16 & 16 & 20 \\
\hline (1)Fem ln. & 483 & 429 & & 445 & 440 & 415 & \\
\hline (6) Fem max. $\varnothing$ & 32 & 27 & 30 & 27 & 26 & 27 & 30 \\
\hline (19) Fem head $\varnothing$ & 49 & 46 & & 46 & 46 & 43 & 41 \\
\hline (2) Patella br. & 48 & 46 & & 49 & 45 & 38 & 35 \\
\hline (2) Tibln. & 398 & $344 \mathrm{R}$ & & 349 & 335 & & \\
\hline (8) Tib Max. Ø & 35 & 30 & 33 & 29 & 29 & 25 & 30 \\
\hline (2) Fib Max. Ø & 14 & 13 & 17 & 14 & 13 & 13 & 21 \\
\hline Metatarsal I ln. & 63 & 67 & 63 & 65 & $62 \mathrm{R}$ & & $56 \mathrm{R}$ \\
\hline (1) Calcanuesln. & 54 & 59 & $65 \mathrm{R}$ & 59 & 56 & 49 & 49 \\
\hline Est. Stature & $1771 \pm 37$ & $1632 \pm 37$ & $1661 \pm 50^{\mathrm{H}}$ & $1673 \pm 37$ & $1660 \pm 37$ & $1596 \pm 42$ & $1552 \pm 37$ \\
\hline
\end{tabular}


Table 2. The presence (+ and count) or absence (-) of most relevant non-metric (epigenetic) traits documented on the eight examined skeletons in this study.

f: foramen or canal; blank: not verifiable; /: separator between right and left side; os.: ossicle; s.: suture; proc.: process; FT: transverse foramen division.

\begin{tabular}{|c|c|c|c|c|c|c|c|c|}
\hline $\begin{array}{ll}\text { Individual } & \\
\text { Trait } & \end{array}$ & $\begin{array}{c}\text { I } \\
\text { KS-1040 }\end{array}$ & $\begin{array}{c}\text { II } \\
\text { KS-1042 }\end{array}$ & $\begin{array}{c}\text { III } \\
\text { KS-1043 }\end{array}$ & $\begin{array}{c}\text { IV } \\
\text { KS-1044 }\end{array}$ & $\begin{array}{c}\mathrm{V} \\
\text { KS-1041 }\end{array}$ & $\begin{array}{c}\text { VI } \\
\text { KS-1045 }\end{array}$ & $\begin{array}{l}\text { CH-79 } \\
\text { KS-1006 }\end{array}$ & $\begin{array}{r}\text { Tower } \\
\text { KS-1039 }\end{array}$ \\
\hline Supraorbital structures & $+/+$ & $+/+$ & & $+2 /+2$ & $+2 /+2$ & +1 & $+2 /+$ & $+2 /+2$ \\
\hline Zygomaxillarytubr. & & $+/+$ & & $-/-$ & $-/-$ & & & +1 \\
\hline Suprameatal spine \& & $+/-$ & $-/-$ & $-/-$ & $+/+$ & $-/-$ & -1 & $-/-$ & +1 \\
\hline depression & $+/+$ & $-/-$ & $+/+$ & $+/+$ & $+/+$ & +1 & $-/-$ & -1 \\
\hline Condylar canal & & $-/-$ & & +1 & $+/+$ & & $+/+$ & \\
\hline Condylar facet double & $-/-$ & $+/+$ & & $-/-$ & $-/-$ & & $-/-$ & \\
\hline Hypoglossal canal & -1 & $-/+$ & & $-/+$ & $+/+$ & & $-/-$ & \\
\hline Paracondylar proc. & $+/+$ & $+/+$ & & +1 & $+/+$ & & $-/-$ & \\
\hline Metopic s. & - & - & - & - & - & - & - & - \\
\hline Supranasal s. & - & - & & - & - & & + & + \\
\hline s. mendosa & - & - & & $+/-$ & $-/-$ & - & $+/+$ & - \\
\hline Squamomastoid s. & $+/+$ & $+/+$ & & $+/+$ & $+/+$ & +1 & $+/+$ & $+/+$ \\
\hline Infraorbital $\mathrm{f}$. & & $-/-$ & & & & $-/-$ & & $-/-$ \\
\hline Parietal f. & $-/+$ & $-/-$ & & $-/-$ & $-/+$ & $-/-$ & $-/+$ & $-/-$ \\
\hline Occipital f. & +2 & + & & +3 & + & + & - & + \\
\hline Zygomatico facial $\mathrm{f}$. & & I- & & $+/+$ & +1 & $+/-$ & $+/+$ & $+/+$ \\
\hline Mastoid f. & $+/+$ & $+/+$ & & $+/+$ & $+/+$ & +1 & $+/+$ & $+/+$ \\
\hline lambdoidos. & - & $-/+2$ & +1 & $+/+$ & $-/+$ & & $+4 /+2$ & $-/+2$ \\
\hline at lambdaos. & - & - & & $-/+$ & - & & - & - \\
\hline Os. at astrion & - & - & & $+/+$ & - & & - & - \\
\hline Occipito-mastoideos. & - & - & $-/-$ & $-/-$ & $-/+$ & & $-/+$ & $-/-$ \\
\hline Ponticulusatlantis & - & - & - & + & + & - & - & - \\
\hline C5-C7 FT division & + & + & & + & - & - & + & - \\
\hline Peroneal process & $-/-$ & -1 & $+/+$ & $-/$ & $-/-$ & $-/-$ & $-/-$ & \\
\hline Stieda's proc. & $-/-$ & $+/+$ & & $-/-$ & $+/+$ & $+/+$ & $+/+$ & $-/-$ \\
\hline $\begin{array}{l}\text { Synostosis in } 5^{\text {th }} \text { toe } \\
\text { (median and distal.) }\end{array}$ & $-/+$ & - & & $+/-$ & - & - & - & \\
\hline
\end{tabular}




\section{Individual-II (KS-1042)}

The nearly complete, relatively whitish, skeleton reveals strong masculine features, such as prominence of the nuchal area, and an ischio-pubic index of $82 \%$. Mainly cranial sutures obliteration and pubic symphyses surfaces suggest an age at death of 45-50 years. KS-1042 has a dolichocephal skull, gracile post-cranial proportions, and an estimated statue of about $163 \mathrm{~cm}$ (Table 1). Further anatomic variants include a bilateral division of the cranial condylar facet and the corresponding superior articular facet on the atlas, and transitional Th11 and Th12 vertebrae.

Porosity on the skull's outer surface is more obvious than in KS-1040. It covers both parietals and extends towards the frontal and occipital bones. There is also a healed cribra orbitalia on the left orbit. The upper part of the left parietal bone reveals a small impression fracture, ca. $0.5 \mathrm{~cm}$ in diameter, and a crescent shaped impression of the lamina externa beneath it, thus suggesting a traumatic injury. A bilateral porosity is manifested at the lamina lateralis of the pterygoid process, as well as new woven bone formation on both sides of the mandibular fossa. There are signs of parodontitis as well as periodontosis on both jaws. Despite no pre-mortem tooth loss, there are only 18 teeth available, most with medium-strong abrasion. Light calculus developed on 10 teeth. There is a carious lesion on the occlusal surface of the right maxillary M2. The ventral mandibular side shows multiple worm-eaten-like defects, which could be artefacts or related to the pathologic condition detailed below.

On the cervical vertebra C6 there is a lytic lesion at the ventral part of the ground plate adjacent to the epiphysis anularis. It reaches the spongy bone of the vertebral body and is surrounded by sclerotic new bone formation. Around this lesion there is a circumscribed porosity (Fig. 6A). A traumatic cause could be excluded, since fractures at this location with no other defects are impossible. Infection in the form of unspecific osteomyelitis is also improbable, since characteristic features of necrosis of the cortex, sequestration, cloacae and periosteal new bone formation are not found. A localized infection in the neck area resulting from wounds or an adjacent soft tissue infection can be excluded since wounds through the neck would be lethal and would not allow surviving long enough to develop a bone reaction. Tuberculosis frequently involves the spine, preferably lumbar and thoracic vertebrae. In most cases more than one vertebra is affected. The infectious lesion is purely lytic leading to destruction of the vertebral body. The subsequent vertebral collapse results in a sharply angular 
kyphosis, i.e. gibbous (Roberts and Manchester 1995, Ortner 2003). As for KS-1042, a cervical vertebra is affected. The defect is neither severe nor purely lytic, but presents with a sclerotic reaction. Hence, tuberculosis can also be excluded. The next possible cause for the lesion on C6 is brucellosis. The disease is transmitted to humans by domestic animal vectors. Brucella melitensis, mainly affecting goats in the Mediterranean area, is transmitted to man primarily through milk and was suggested to have a long history in this region (Rashidi et al. 2001, Guler et al. 2014). The most common skeletal lesions are on the spine or the sacroiliac joint (D'Anastasio et al. 2011). The spinal lesions are located in the vertebral bodies, especially of the lower thoracic, lumbar, and lumbosacral. Unlike tuberculosis, brucellosis does not result in vertebral collapse and angular deformity. The earliest and most common lesion of the spine occurs as a small destructive focus on the superior, anterior margin of the vertebral body. This destructive early phase is followed by sclerotic repair of the lytic focus that often results in bone formation extending around the margin of the lesion (Capasso 1999, Curate 2006, D’Anastasio et al. 2011). Brucellar spondylitis may also involve the ground plate of a vertebra (Curate 2006, Colmenero et al. 2008). Though the lumbar vertebrae are the most frequently involved, followed by the thoracic ones, cervical vertebrae can also be affected (Rotes-Querol 1957, Lifeso et al. 1985, Tekkök et al. 1993, Solera et al. 1999, Geyik et al. 2002, Gokhale et al. 2003, Ariza et al. 2007, Colmenero et al. 2008, Ramosaço et al. 2017). C6 of KS-1042 reveals similar vertebral lesions to earlier reported brucella cases on dry material (comp. Curate 2006, Mays 2007, Anastopoulou et al. 2017). Hence, the pathological condition on this vertebra is well compatible with the diagnosis of brucellar epiphysitis. The dorsal part of the upper plate of the sacrum reveals a similar erosive brucellar lesion to that on C6 (Fig. 6B). The involvement of the sacrum in brucellar infection as well as the posterior margin of vertebrae is not unusual (Rotés-Querol 1957, Exteberria 1994, Bouaziz et al. 2007, Colmenero et al. 2008, Yang et al. 2014). It remains uncertain whether the lesions on the mandibular pterygoid (Fig. 6C) and the ventral mandibular side are also related to this infection.

There are minor to medium signs of DA at the vertebral column, with maximum spondylosis at the middle of C3/4, Th12/L1, and L5/S1. The only Schmorl's node is on the upper plate of L5. Spondylarthrosis is also mild. The right fovea costalis transversi of Th8 reveals a typical osteochondrosis dissecans lesion. The costovertebral joints reveal increasing DA in caudal direction to reach a maximum at the $11^{\text {th }}$ rib. DA of the 
limbs are mild to medium as on the sacroiliac joints, the left sternoclavicular joint, both hips and the left wrist. The small joints of the hand and feet bones are unsuspicious. In contrast to the relatively mild degenerative changes at the joints and the vertebral column, there are marked enthesopathies at the right olecranon, the left patella, and the insertion of Achilles' tendon at the right calcaneus (left not available). The left clavicula exhibits a rarifying form of enthesopathy at the insertion of the coraco-clavicular ligament. The right ulnar styloid process is deformed, probably as a result of a healed fracture.

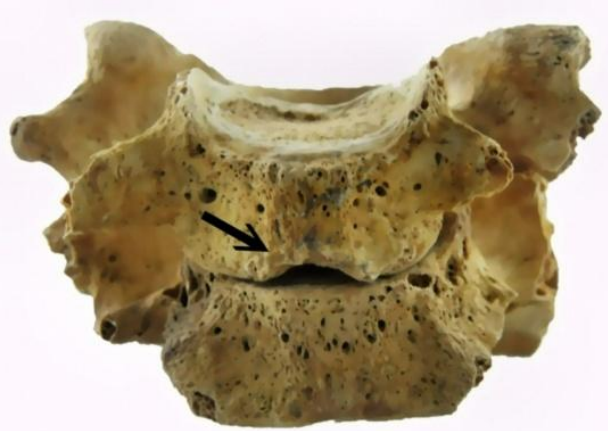

A)
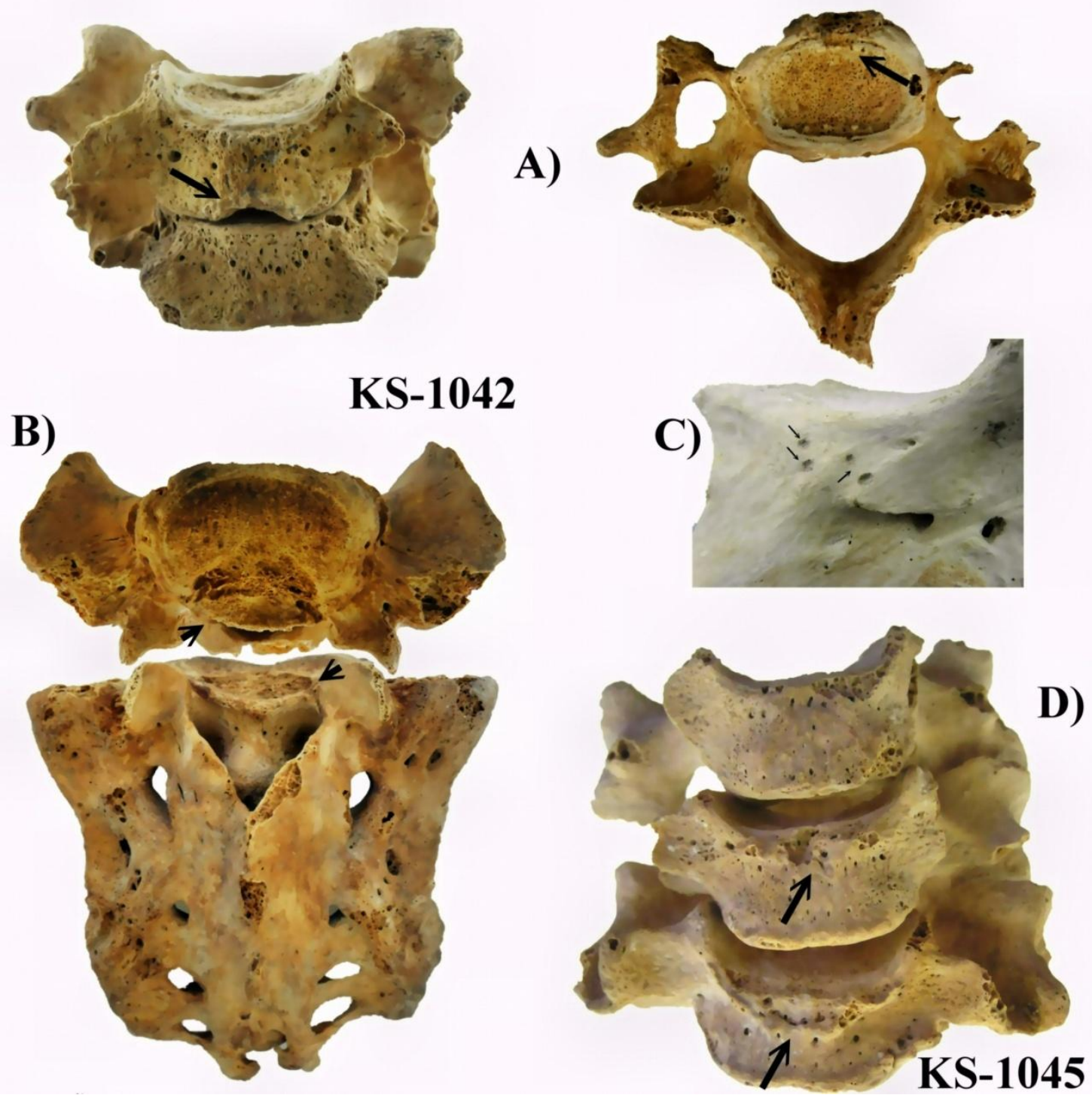

Fig. 6 Brucellosis lesions (arrows):

A) on the C6 of KS-1042; B) on the dorsal side of the first sacrum segment; C) the worm-eaten-like defects on the left mandibular inner side of KS-1042; and D) on C4 and C5 of KS-1045. 


\section{Individual-III (KS-1043)}

The bones of this individual were easy to differentiate as those of a sub-adult. They are very fragile and fragmentary so that only about $50 \%$ of the skeleton is available for analyses. All deciduous teeth had erupted, but the permanent M1s, an incisor, canines and a premolar not yet. This allows estimating an age at death of $5 \pm 1$ year. Mandibular features and a relative narrow sciatic notch of the pelvic bone are among the traits that indicated a male child. KS-1043 has 6 lumbar vertebrae. The cervical and thoracic vertebrae and the sacrum are incomplete.

The skull's lamina interna, at the frontal and occipital bone, and to a lesser extent both parietal bones, reveals pronounced impressions of the cerebral gyri (Fig. 8A). This could be due to normal growth, but also pathological. The lamina interna of the skull base displays a deposition of trabecular bone beside a fine porosity and deposition of woven bone at another fragment. There is also porosity at the nasal base, and even stronger at the palate and parodontium (Fig. 8 B-C). Further woven bone and a fine porosity are at the inner left side of the mandibular bone. These observations suggest a local inflammation with maximum in the mouth's area, nose, and skull base. In children, the main origin of such an infection is the middle ear (Roberts and Manchester 1995, Thomas et al. 2014), but in this case the outer and inner ear, mastoids and pyramids are not suspicious. A sinusitis as cause for this infection is improbable, since there is only a light porosity at the bottom of both maxillary sinuses. There are no dental abscesses so that the origin of the infection remains obscure. Marked porosity and woven bone are also present on some ribs, nearly all metaphyses of the long bones and at the ventral aspect of the vertebrae, which could be growth-related, though some are acute. Furthermore, there is a marked porosity at the endost of the right humerus, alongside the linea aspera of the right femur and at the right ala of the ileum, which is not physiological but most probably due to an infection (Fig. 8 D-G).

It appears that KS-1043 had suffered from an infection, the source of which was probably in the area of the mouth and nose. The infection spread locally to the skull base, where the basal meningitis caused an increased cerebral pressure and hence the impressions digitate of the lamina interna (comp. Eerkens et al. 2018). The infectious 
signs at the post-cranial bones reflect a generalization of this infection, i.e. sepsis. Both, meningitis and sepsis could have been lethal.

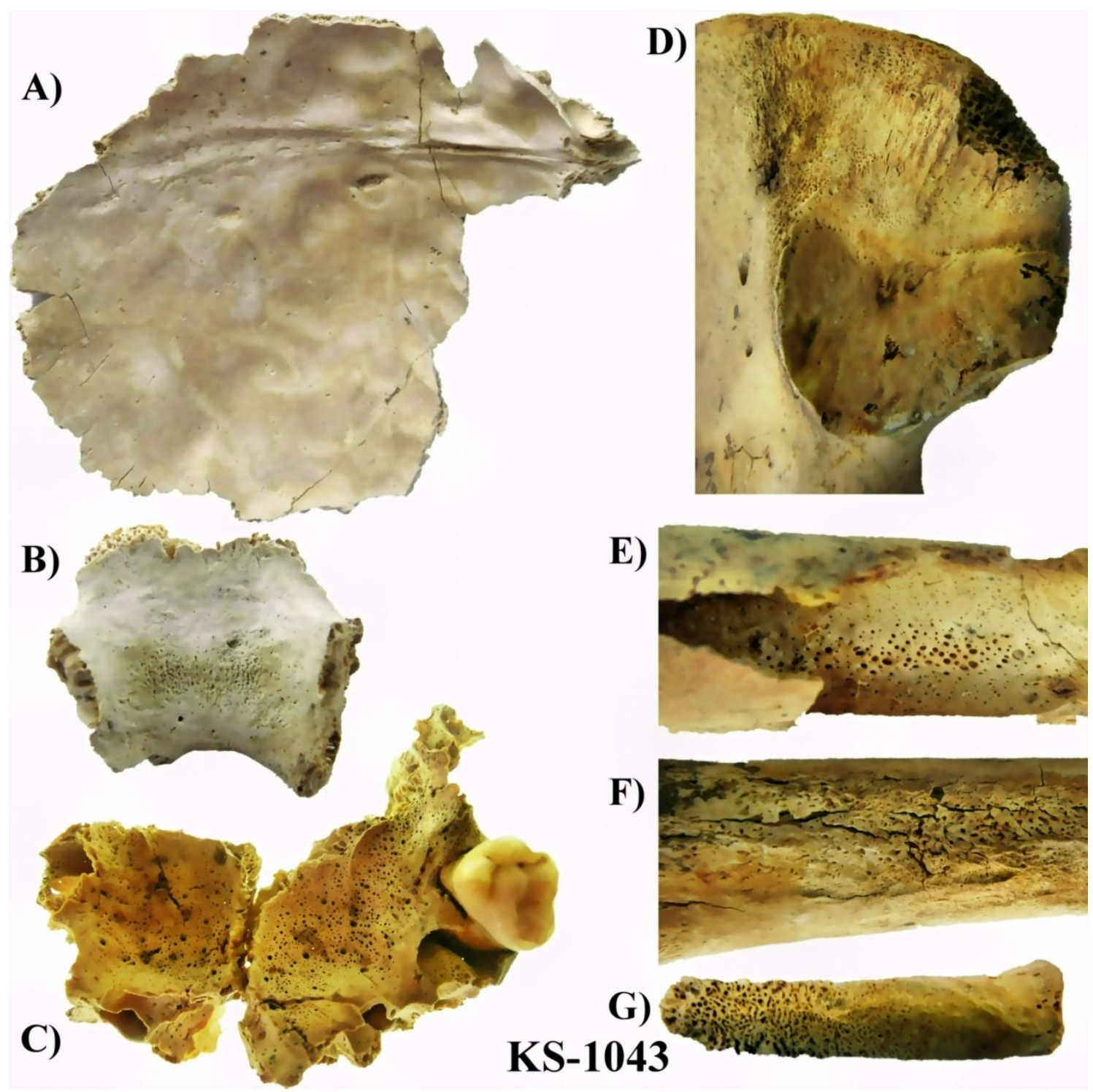

Fig. 8 Features of septic infection on the child's skeleton KS-1043:

A) impressions digitate on the inner surface of the frontal bone; porosity and woven bone formation on (B) the basilar part of the occipital bone, C) maxilla, D) the ilium of the right pelvic bone, E) right humerus, F) left femur, and $G$ ) a rib (all not scaled). 


\section{Individual-IV (KS-1044)}

Nearly 75\% of KS-1044's skeleton was available for analyses. Both cranial and pelvic features indicate a male of an estimated age at death of 45-55 years. All bones of KS-1044 are relatively light and the spongy bone exhibits rarified but coarse trabeculae seen usually in osteoporosis. Studies on recent populations showed that the incidence of osteoporosis among males below 50 years of age is not unusual but the etiology is diverse (Stini 1990, Adler 2011, Thomasius et al. 2018, Sidlauskas et al. 2014, Radi and Karaplis 2017). The skull is marginally dolichocephal. The gracile long bones suggest a stature of $166 \pm 5 \mathrm{~cm}$ (Table 1). The anatomic variants (Table 2) also include a possibly none pathologic bone formation at the dorsolateral side of the $5^{\text {th }}$ left metacarpal.

There is marked porosity around the superciliary area of the skull that probably resulted from a local infection near the eyebrows. The strong porosity on the palate and in the vicinity of the dental sockets is indicative of gingivitis and parodontitis, which caused parodontosis. KS-1044 lost 21 teeth before death and in place of two teeth there are huge cavitations that could either be alveolar abscesses or fresh unhealed sockets. Of the remaining teeth, two were broken during life time, and only two remained on the left side. A medium periodontosis developed around the teeth with strong abrasion but no calculus. Caries is restricted to the mesial neck of the $1^{\text {st }}$ lower right premolar. The strong DA on the right temporo-mandibular joint had probably resulted from the missing teeth on the left side as chewing was very likely restricted to the right side during his last years.

The vertebral column shows marked spondylosis at the C5/6 and 6/7 and moderate uncarthrosis at the middle cervical vertebrae. Even the spinal processes of $\mathrm{C} 2$ 5 and $\mathrm{C} 7$ were involved in the degenerative process as they reveal strong coarse porosity. Spondylosis at the lumbar vertebrae is medium strong on the L1/2 and L4/5 with pronounced spondylophytes on the left side of L2 and L3 and on the right side of L4 and L5. This was probably a reaction to the light, osteoporotic, compression fracture on the left side of L1, above and below which there is strong spondylarthrosis on the right side of Th12/L1, L2/3 and L3/4. Other vertebrae with marked spondylarthrosis are Th3/4 and Th4/5. The ligamentum flavum is partly ossified between Th5 and Th11, while Schmorl's nodes developed on the ground plates of Th10, Th11, L1 and L2. Strong degenerative changes on the upper extremities developed bilaterally on the sterno- and acromio-clavicular joints, to a lesser degree on the shoulder joints as well as 
on the right radioulnar joint. The right circumferential articularis radii reveals an irregular small depression with signs of healing, probably osteochondrosis dissecans. On the lower extremities, the right sacroiliacal as well as the right hip joints reveal strong DA. The left femoral head as well as the other joints are missing. DA at the hands are restricted to the right $1^{\text {st }}$ metacarpophalangeal, the $1^{\text {st }}$ distal interphalangeal and the left $5^{\text {th }}$ distal interphalangeal joints. On the feet, DA are restricted to the right $5^{\text {th }}$ proximal and $2^{\text {nd }}$ distal interphalangeal joints. Enthesopathies are only found on the right humerus, behind the tuberculum minus.

There is an impression fracture at the joint surface of the base of the $3^{\text {rd }}$ right medial phalanx of the hand. The midshaft on the left side of this phalanx has a huge bony process that might suggest an involvement of the tendon in this trauma. Consequences of traumatic injuries are also observed on the feet bones. The joint surface of the base of the $5^{\text {th }}$ metatarsal shows a step formation as well as a bony apposition at the tuberositas (Fig. 7E). Another step formation is observed on the proximal joint surface of the right foot's $2^{\text {nd }}$ median phalanx.

\section{Individual-V (KS-1041)}

Only about $70 \%$ of KS-1041's skeleton was present. The available cranial and pelvic features indicate a male individual of an estimated age at death of 55-65 years. KS-1041 has a dolichocephal skull, gracile long bones, and a stature of about $167 \mathrm{~cm}$ (Table 1). The epigenetic traits (Table 2) also include a $45^{\circ}$ medially rotated left mandibular canine, possible constitutional bilateral absence of the maxillary M3. The larger jugular foramen on the right side, with smooth margins, might be an epigenetic variant, though it can also result from a benign tumour (Caldemeyer et al. 1997, Vogl and Bisdas 2009, Altenburger 2009).

Individual-V lost at least 5 mandibular teeth long before death and the bone is already atrophic. The maxilla reveals marked porosity consistent with parodontitis and gingivitis, which lead to strong periodontosis. The remaining teeth show medium abrasion, calculus at 5 of them, but no caries. Around the medial and lateral roots of the right M1 there are dental abscesses that penetrated the floor of the right maxillary sinus. It appears that the minor porosity in both maxillary sinuses resulted from a chronic sinusitis rather than the abscess penetration. Dental abscesses had also developed on the left maxillary M1 and M2. 
The vertebrae display medium DA with a strong spondylosis at C5/6, and medium at Th10/11. The Th11 and Th12 vertebrae are wedge shaped as a result of compression fractures that were probably caused by the deep Schmorl's nodes at the upper plates of these vertebrae (Fig. 7B). The skeleton of KS-1041 reveals no signs of osteoporosis. The ossification of the ligamentum flavum increases from Th3 to Th11, and to a lesser extent from L1 to L3. Degenerative changes at the sacroiliac and the left sterno-clavicular joints are mild to medium and minor on both hip and knee joints. All other available joint surfaces show no signs of arthrosis, including the hands and feet. The femur's condylus medialis on the left reveals a typical osteochondrosis dissecans. Enthesopathies are restricted to the lower extremities, at the fossa trochanterica and in front of the lesser trochanter on both sides, at the ventral side of the left patella, at the fossa malleoli of the left fibula, and at the insertion of Achilles' tendon at both calcanei.

On the medial side of the right fibula, about $5 \mathrm{~cm}$ from the distal epiphysis, there is a tumour of ca. $1 \mathrm{~cm}$ diameter. It consists of normal spongy and compact bone, whereby the last appears like woven bone. These features characterize the bony base of an osteochondroma, a benign bone tumour (s. b.). The corresponding side on the tibia reveals a slight depression and a light sclerosis of the compacta, which exactly fits with the osteochondroma on the fibula (Fig. 9B).

\section{Individual-VI (KS-1045)}

The available material represents nearly $60 \%$ of the whole skeleton. A number of cranial and pelvic features indicate a male individual who died at the age of 40-45 years, though others, such as teeth condition (see below), might indicate an age above 50 years. KS-1045 has a mesocephal skull, gracile long bones, and a stature of about $166 \mathrm{~cm}$ (Table 1). The anatomic variants (Table 2) also include a fusion between the sternal body and xiphoid, os acromiale only on the left scapula, a bilateral vatus notch at both patellae, as well as patella bipartite on the right (Fig. 4D).

Minor porosity on the frontal, occipital and parietal parts was probably related to head lice, as earlier suggested. The right side of the frontal bone reveals a healed impression fracture consisting of a shallow impression of about $2 \mathrm{~cm}$ diameter in the middle of which is a ring-shaped new bone formation of $0.5 \mathrm{~cm}$ diameter (Fig. 7C).The lamina interna is not suspicious. This trauma was probably caused by a solid, spherical object, e.g. stone. KS-1045 lost the mandibular P2 and M3 prior death leaving 
completely healed sockets. Most teeth show strong abrasion, with mild calculus on 13 of the remaining 22 teeth, but no caries.
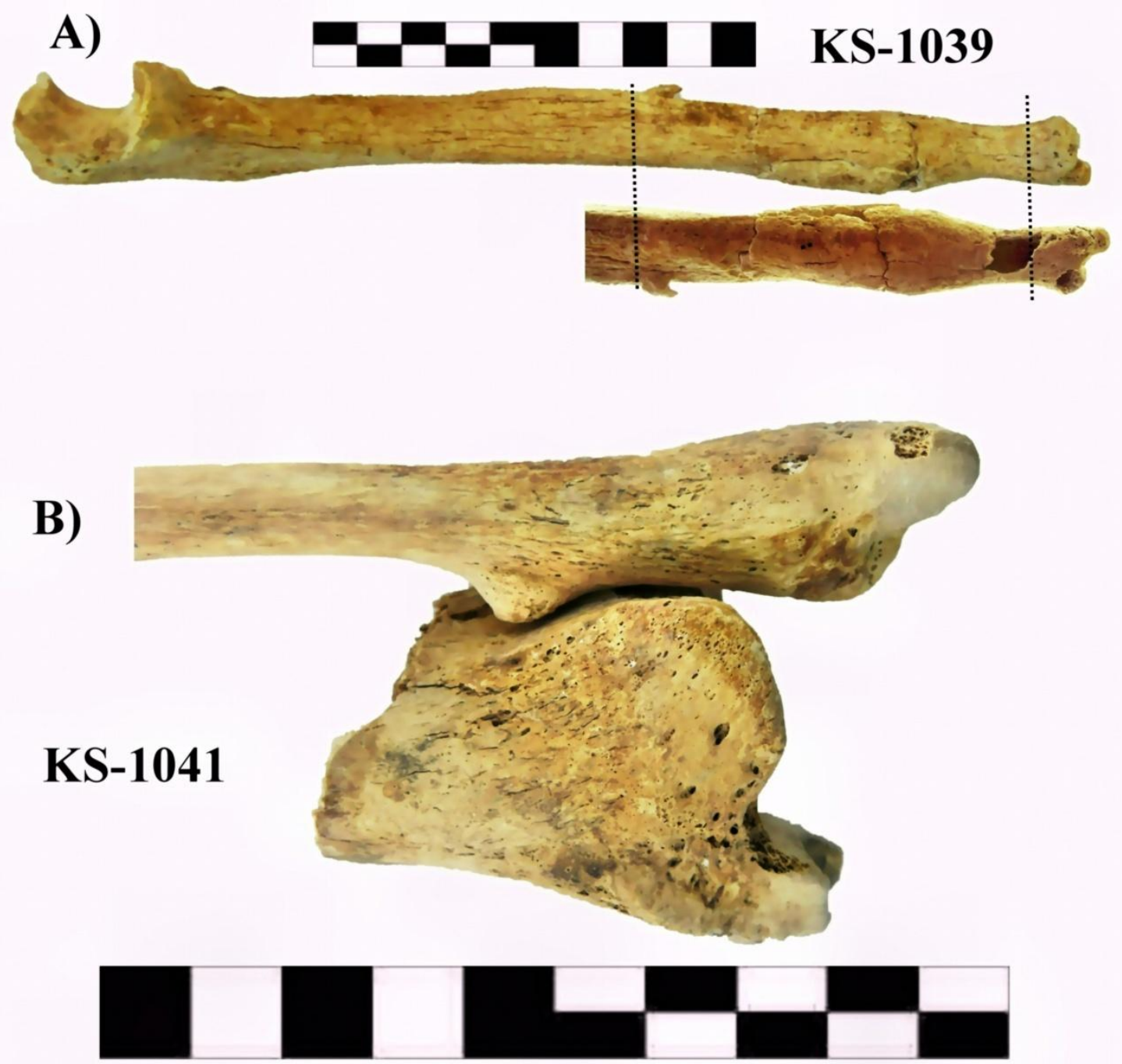

Fig. 9 Tumours:

A) Ventral and dorsal (smaller) view of KS-1039's left ulna revealing enchondroma (swelling) and osteochondroma (spike) cases; B) Osteochondroma at the distal end of the left fibula of KS-1041 affecting the opposite surface on the left tibia.

Osteochondrosis dissecans is manifested at the median condyle of the right tibia and the left upper articular process of C4 and C5. Small Schmorl's nodes are at the upper plate of Th8 and the ground plate of Th9. The DA of the spine are medium with maximal spondylosis at $\mathrm{C} 6 / 7, \mathrm{~L} 2 / 3$ and $\mathrm{L} 3 / 4$, and the costovertebral joints. There is a minor uncarthrosis and no relevant spondylarthrosis. The ligamentum flavum between Th7 and Th10 is partly ossified. DA at the extremities are mild, particularly at the left 
acromio-clavicular joint, the left sacroiliacal joint and knee, and the available hand and feet joints. There is a defect at the ventral part of the upper plate of C4 and C5, 2 and $10 \mathrm{~mm}$ in length respectively. Both lesions revealed sclerosis at the bottom and are surrounded by new bone formation (Fig. 6D). These lesions are not only similar but even more typical for brucellosis than in the case of C6 of Individual-II.

\section{B- Church-79 Tomb}

The tomb excavated in August 1993 was first localized in 1985 in a side room adjacent to the northern entrance of Church 79. It was dug alongside the church's northern wall (Fig. 10). After removing the tomb's filling, the covering slabs were reached at about $120 \mathrm{~cm}$ from the cleared room surface. The roughly cut and rectangular basalt covering stones, varying between $74 \times 27 \times 8 \mathrm{~cm}$ and $39 \times 12 \times 10 \mathrm{~cm}$, rested upon $15 \mathrm{~cm}$ broad shoulders on all four sides of the burial pit and slightly lower along the southern side. The slabs were fixed by small pebbles and sealed with mud. Inside the $170 \times 45 \times 40 \mathrm{~cm}$ burial pit, the articulate skeleton of an adult was found covered by 1-3 $\mathrm{cm}$ of fine earth that had silted through the slabs. The burial was in a West-East orientation. The skull rested on a small flat stone and lowered towards the chest. The right hand was placed crossed over the left below the chest. The deceased wore a simple bronze ring on the right $4^{\text {th }}$ proximal phalange. A small bronze coin ( $7 \mathrm{~mm}$ diameter $)$ was placed in the "mouth" and small leather fragments ( $\cong 2 \mathrm{~mm}$ size) were scattered around the pelvic bone. The tomb was dated to the $7^{\text {th }}$ century AD. It was assumed to be of a (male) benefactor mentioned in a mosaic inscription on the central church's nave reading: “(...) Kasiseos, deacon and paramonarios” (Humbert 1993).

The nearly intact skeleton KS-1006 smells slightly perfumed and is of light brown colour. The bones are fragile and generally "light" with much fragmentation and deterioration, particularly of the small and dorsal skeletal parts, e.g. vertebral arches, ribs, and joints of some long bones. The skull reveals a light prominence of the glabella area and a flat nuchal area, while the pelvic bones show an elevated pubic ridge, narrow ischio-pubic ramus, and a slightly greater than $90^{\circ}$ sciatic notch and sub-pubic angles. These features suggest a female burial, yet they remain marginal. For further verification, ancient DNA (aDNA) analyses were performed to achieve a molecular sex determination of individual KS-1006 at the Institute for Mummy Studies of Eurac Research in Bolzano (Italy). The analyses were carried out on a premolar with jawbone 
fragments as well as on the left medial cuneiform bone, the most suitable parts available for molecular analysis. Yet, both samples were not well preserved and extremely porous. Silica-based DNA extractions were performed according to procedures described by Damgaard et al. (2015), Rohland et al. (2010) and Dabney et al. (2013). Polymerase chain reaction (PCR) analyses of 45 cycles were done. Seven targeted the nuclear sex-specific markers DAZ (68 bp) (Stanghellini et al. 2006), SRY (66 bp) (Graefen 2009) and Amelogenin (106/112 bp) (Sullivan et al. 1993). No positive results were obtained. Three PCR tests targeted the two mitochondrial markers, 12S rRNA (146 bp: 1066-1211) and HVR1 (162 bp: 16287-16410), which could only provide an indication of some residual endogenous DNA.

In addition to the pubic symphyses surfaces, KS-1006 reveals extensive premortem tooth loss as well as deteriorated spongiosa. These observations suggest an age at death well beyond 60 years. KS-1006 has a rounded brachycephal skull, and a stature just below $160 \mathrm{~cm}$ (sex independent). In addition to the anatomic variants listed in Table 2, KS-1006 also reveals a left parietal notch bone (Fig. 3) and synostosis between manubrium and sternal body.

Twenty of the 32 teeth were lost long before death leaving healed sockets, and mostly atrophic jaws. The remaining teeth show medium periodontosis and evident signs of parodontitis and gingivitis. There are apical abscesses at the maxillary right canine and the left PM1. It appears that the severe abrasion of the last remaining molar, with consecutive opening of the alveolar channel, lead to abscess formation followed by tooth loss.

All bones of KS-1006 are extremely light. The occipital bone reveals porosity with straggly bone architecture at the skull base and both ischia parts. These are signs of osteoporosis, which is more frequent among females (Stini 1990, Aufderheide and Rodriguez-Martin 1998, Zaki et al. 2009). The DA of the spine are manifested as marked spondylosis between the lumbar vertebrae L3/4, L4/5 and L5/S1, and to a lesser extent between $\mathrm{Th} 9 / 10, \mathrm{~L} 1 / 2$, and L2/3. The alterations are also severe at the atlantoaxial joint and on the right articular facets of $\mathrm{Th} 3 / 4$, less on the right side of $\mathrm{Th} 2 / 3$, and mild on the remaining vertebrae. They are mild on the sterno-clavicular joints, the right shoulder, and the left elbow, left radio-ulnar joint and right hip. All other available joints show no sign of degenerative disease. Osteochondosis dissecans is present on the base of the foot's left $1^{\text {st }}$ proximal phalanx. Both calcanei reveal an enthesopathy at Achilles' tendon insertions. 

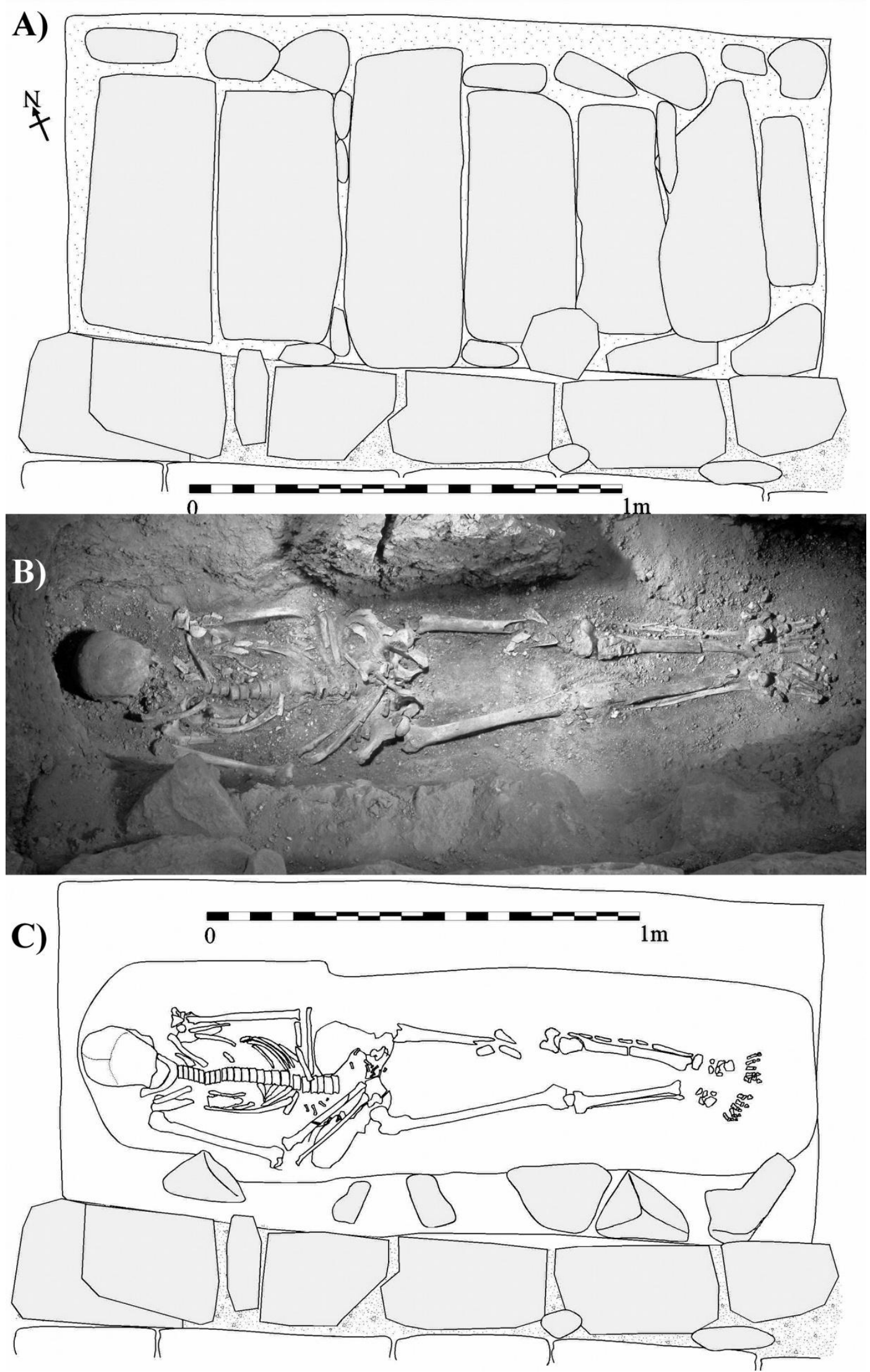

Fig. 10 Top views of Church-79 tomb:

A) the closed tomb; B) in situ skeleton (J.-B. Humbert); C) the burial. 


\section{C-The "Tower-Tomb" (KS-1039)}

The tomb was found at the end of the "corridor" leading to the entrance of the northwestern Tower 35 in the Roman fort and excavated in 1987 (Fig. 11). It was covered by a heap of basalt stones and marked by another basalt stone engraved with a crude cross. This burial was therefore associated with the decline phase of the Christian settlement in the $9^{\text {th }}$ AD century (Humbert 1987). The burial was at less than $1 \mathrm{~m}$ depth, on a light slope in front of an ancient stone entrance. The deceased was buried in a stretched position, head westwards. The left femur was inverted near the left arm but the associated lower parts were anatomically in situ. The bones are brittle and of a whiteyellowish colour with some "peeling sheaths" of bone on the surface. Fragmentation had already occurred prior excavation, so that only about $80 \%$ of the skeleton was available for analyses. Many articulation surfaces indicate incomplete decay of the bone's organic substances inside. There are bright pink coloured areas in the diploë. Similar colorations were suggested to result from the interaction of high levels of purple acid phosphatase enzyme with trace elements, such as iron, manganese, zinc, and copper in an acidic milieu (Cole and Waldron 2016, Cole 2017), as in the case of Khirbet es-Samrā area.

Multiple cranial and pelvic features indicate a male with an estimated age at death of 25-35 years. The osteometric measurements reflect a mesocephal skull, robust long bones, and a stature of $155 \mathrm{~cm}$ (Table 1). Further anatomic variants (Table 2) include an irregular position of the right maxillary canine between the two premolars and a rotation of $90^{\circ}$, a bilaterally not erupted $3^{\text {rd }}$ mandibular molar, Stafne's cyst (comp. Lukacs and Martın 2002); a bilateral absence of the fovea costalis transversalis of Th10 combined with bilateral present fovea costalis. Also, there is a cranial shifting on the left side of the vertebral column involving the Th12 and the L1 vertebrae. Th12 has a thoracic processus articularis inferior and fovea costalis with a rudimentary rib on the right and a lumbar processus articularis inferior with no fovea on the left, while L1 has a thoracic processus articularis superior on the right and lumbar one on the left. It is thus probable that KS-1039 had 12 ribs on the right and 11 on the left side.

Except for minor porosity on the lamina externa of the right parietal bone, the available cranial parts reveal no significant pathological features. The vault has a normal thickness, and no cribra orbitalia. Bad oral hygiene is indicated by calculus on 
14 of 29 examined teeth, with consecutive parodontitis and gingivitis. Also, there is a mild enamel hypoplasia on the upper right $2^{\text {nd }}$ incisor.

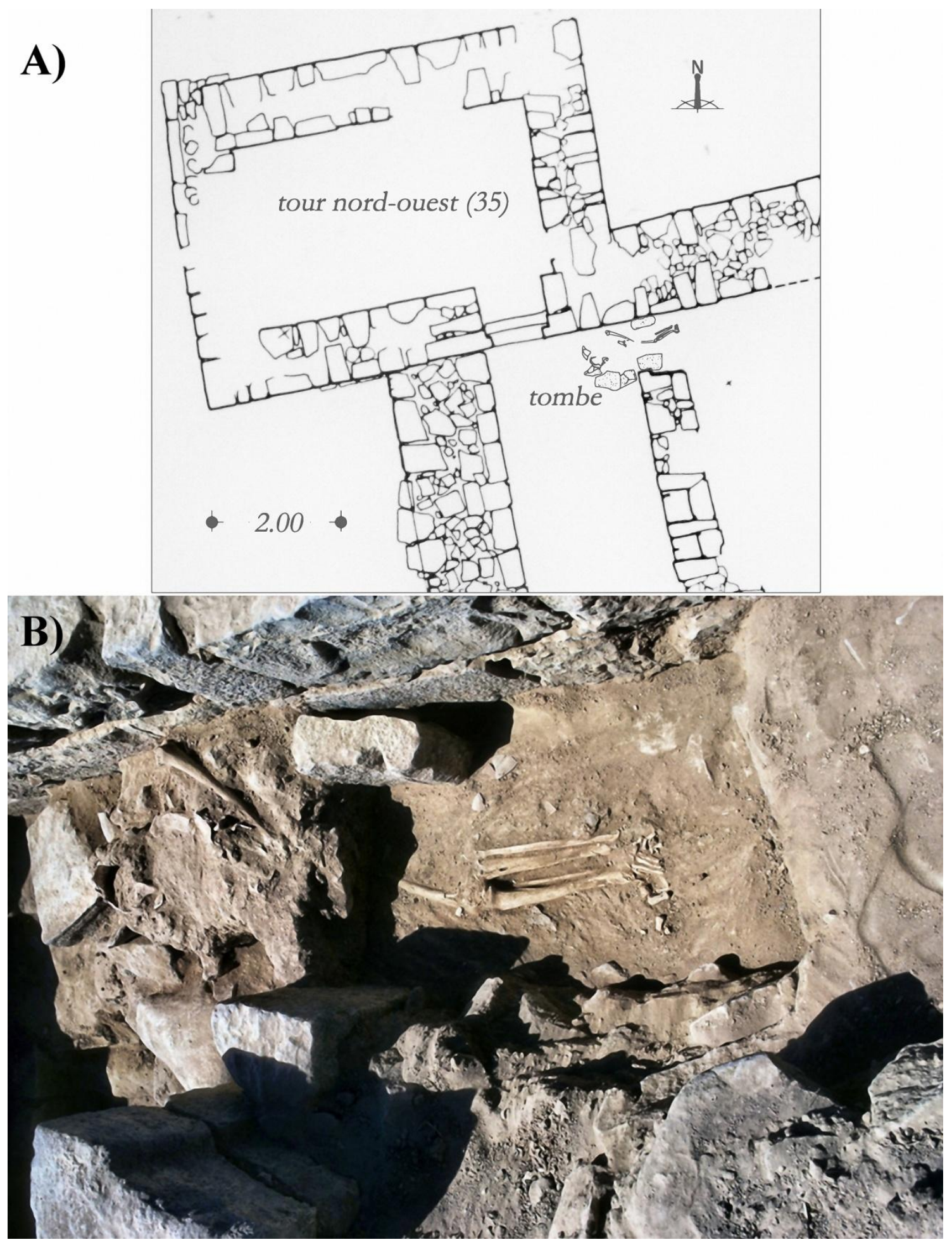

Fig. 11 The "Tower tomb" burial KS-1039:

A) top view drawing of the excavated burial; B) the burial. Notice the disposition of the left femur near the left arm (source Humbert and Desreumaux). 
The DA are consistent with the estimated age, though mostly on the available right side parts. On average, they are mild on the long bones and vertebrae, with medium spondylarthrosis, particularly in the middle thoracic vertebrae, as well as a partial ossification of the ligamentum flavum in the middle and lower thoracic vertebrae. Small Schmorl's nodes are on the lower plate of Th10, and upper plate of Th11 and L1. Of the available small hand and feet joints, only the $1^{\text {st }}$ right metacarpophalangeal joint is with mild DA. The right foot's $5^{\text {th }}$ phalanx proximalis is deformed but with no indication of injury or inflammation, with only strong degenerative changes at the base. Furthermore, both phalanges proximales I of the feet reveal osteochondrosis dissecans. There is an enthesopathy on the right calcaneus, at the insertion of Achilles' tendon. The left is missing.

In the vicinity of the distal metaphysis of the left ulna there is a $19 \mathrm{~mm}$ diameter swelling of the diaphysis (Fig. 9A). The compacta is slightly rarefied and compressed from inside. The bone is otherwise inconspicuous, particularly with no sign of any destructive or infiltrative growth or a periosteal reaction. These observations indicate a benign tumour (chondroma) inside the bone, i.e. enchondroma. Chondromas consist of hyaline cartilage that vanishes in ancient skeletal material. They are mostly solitary, but can occasionally involve more than one bone or site in a single bone with an incidence of $10-25 \%$ of all benign bone tumours (Jaffe 1958). The tumours may cause pain and pathological fracture, but usually they cause no symptoms and function is not impaired (Fletcher et al. 2002). About $3 \mathrm{~cm}$ above this tumour, there is a "spike" of mature bone at the margo interosseus, in addition to a very similar bone structure on the mid-shaft of the left fibula (Fig. 9B-C). These lesions are typical osteochondromas, as also the case of KS-1041's left fibula. Osteochondromas arise in bones performed by cartilage and consist of a bony base or pedicle and a cartilaginous cap. They are relatively common and were reported to represent ca. $35 \%$ of benign bone tumours, $15 \%$ of them are multiple, and their inheritance is autosomal dominant (Khurana et al. 2002). The most common sites of involvement were suggested to be the metaphyseal region of distal femur, upper humerus, upper tibia and fibula, as well as ulna (e.g. Kim et al. 2003, Mohammadi et al. 2012). It is uncertain whether the case of KS-1039 with 2 involved tumour locations was random or inherited.

An iron arrowhead, found in situ, caused the traumatic injury on the left lateral side of Th11 vertebral body (Fig. 7D). There is no bone reaction to the injury, thus suggesting that the trauma was directly pre-mortem. The injury to the vertebral body 
itself was certainly not lethal, but on its way through, the arrow could have injured the spleen and/or left kidney and so induced a fatal bleeding. Therefore, this trauma might have been lethal, but must not.

\section{Discussion}

The examined human skeletal remains were obtained from three tombs found within the ancient settlement in Khirbet es-Samrā, and therefore were archaeologically associated with its local Christian population of the $6^{\text {th }}$ to $9^{\text {th }}$ century AD (Humbert 1987, 1993, 1998). The archaeological evidence supported dating the two church tombs of Room-94 and Church-79 within the $7^{\text {th }}$ century AD. As for the "Tower Tomb" found in the rubble of the Roman fortress, the dating to the $9^{\text {th }}$ century AD rested solely on the presence of a cross-engraved tombstone on top of the pile of stones covering this burial. Yet, there are a number of arguments that clearly indicate that KS-1039 cannot be associated with the ancient settlement of Khirbet es-Samrā nor with its local population. First: excavations in Khirbet es-Samrā cemetery showed that adult human bones in shallow burials, i.e. 120-150 cm depth, were always nearly completely disintegrated (comp. Nabulsi et al. 2009). KS-1039 bones reveal incomplete decomposition of organic substances and the bone surface's "sheathing" might have resulted from exposure to sunlight. Second: the above mentioned archaeological context of this burial, mostly stones and less earth covered, tends to reflect an act of a discarding rather than a proper burial of a deceased, though the displacement of the left femur remains obscure. Third: despite the intermediary position of his cranial index among all examined adult skeletons, KS-1039 has the highest cranial width and the lowest least frontal and ast-ast breadths. His long bones are the shortest and of the highest diameter values, i.e. robust. The breadth of his available major joints and the size of the small compact bones are the lowest and even lower than those of the female KS-1006, e.g. femoral head diameter, patella, and calcaneus (Table 1). These observations reflect a different biological picture for KS1039 than that of the buried in the two church tombs. Fourth: the arrowhead injury is no proof of the burial's "antiquity". Such weapons were still in use in this region well into the $19^{\text {th }}$ AD century, as reported by some travellers (e.g. Addison 1838, Francis 1847, Singer 1995). It is thus obvious that the "Tower Tomb" burial was only a few centuries old, i.e. Ottoman, and that $\mathrm{KS}-1039$ is neither related to the ancient Byzantine 
settlement nor to its ancient peoples. The circumstances of this "cross-marked" burial remain unclear.

The osteometric data of the six adult burials from Room-94 and Church-79 tombs reveal some variations in the cranial and more homogeneity in the postcranial values. These observations are reflected in the cephalic index and the gracile long bones (Table 1). All measurements remain within those obtained from the nearby ancient cemetery (comp. Nabulsi 1998). Each of the seven skeletons from the two church tombs reveals a "distinctive" anatomic variant, e.g. the fused articulation facets of KS-1040's tali and calcanei, the parietal notch bone of the female KS-1006, and the six lumbar vertebrae of the child KS-1943. Yet, the variants listed in Table 2 tend to provide more similarities than differences between them. What could be of more significance is the incidence of a number of low-frequency or rarely reported epigenetic traits among them. The available comparative data provided frequencies of transverse foramen division (FT) on single cervical vertebrae, suggestively independent inheritance, and not on the incidence in C5 to C7 en bloc. These values varied between 1 and $40 \%$ (e.g. Aydinlioğlu et al. 2001, Mishra et al. 2014, Yadav et al. 2014). Hence, a calculated combined frequency of FT on C5-C7 vertebrae could be well below 5\%. Reliable data on the distribution of bilateral Stieda's process are still missing (comp. de Vasconcellos et al. 2013, Reddy 2015). Low incidences were already reported for bilateral peroneal process (Hyer et al. 2005) and ponticulus atlantis (Pérez et al. 2014). Synostosis of $5^{\text {th }}$ toe incidence varied between 11.8 and $80.4 \%$ and the bilateral incidence "may be used in kinship analyses" (Teegen and Schultz 1999). Complete or incomplete FT bipatita on C5, C6, and C7 vertebrae (Fig. 4A) and a bilateral Stieda's process of the talus (Fig. $4 \mathrm{E}$ ) are found in four skeletons, while each of the bilateral peroneal process of the calcaneus, ponticulus atlantis, and synostosis in the $5^{\text {th }}$ toe are manifested twice (Table 2). Beside FT bipatita on the C5 to $\mathrm{C} 7$ and Stieda's process, KS-1006 shares the rare mendosa suture (Fig. 4B; comp. Ullinger 2010) with KS-1044 from Room-94 tomb. Though proofing biological relatedness between individuals based on non-metric variables is a highly disputed subject (e. g. Berry 1975, Rösing 1981, Slavec 2005, Velemínský and Dobisíkova 2005, Burrell 2018), the incidences of these less common traits in a small population of about 400 inhabitants as that of ancient Khirbet es-Samrā (Nabulsi et al. 2007) tend to indicate kinship between those buried in Room-94 tomb. In addition to these, the inclusion of a child burial in this tomb might support the hypothesis that it was used during the $7^{\text {th }} \mathrm{AD}$ as a familial burial place for male 
individuals. These in turn might also be related to the female in Church-79 tomb. It must thus be stressed that the previous arguments are only meant to hint upon a possible relatedness and not a proof of it. Unfortunately, this assumption cannot presently be verified using more sophisticated methods like aDNA. The negative and poor results of KS-1006 samples were very likely caused by highly degraded DNA of the badly preserved bones. Preservation of aDNA in bone samples from desert areas, including Khirbet es-Samrā, is known to be extremely poor (Hofreiter et al. 2015). Fragmented aDNA strands have an average range of 30 to 90 bp (Kirsanow and Burger 2012) when strands of more than $60 \mathrm{bp}$ are required for a classical PCR analysis (Rizzi et al. 2012). Given the bad preservation condition of the available material, a more accurate result is not guaranteed even if more sophisticated and costly methods are applied. Furthermore, obtaining suitable and intact samples of the same anatomical part from each skeleton is hampered by the bone condition in the partly comingled burials.

All six adult burials from the two church tombs were estimated to have lived beyond the age of 45 years. The observed degenerative alterations are consistent with the estimated ages, except for KS-1006, who shows less than expected for a senile female. The skeleton of the five adult males buried in Room-94 tomb reveal signs of exposure to prolonged physical stress or activity, possibly occupational. This is indicated by a number of pathological features, e.g. osteochondosis dissecans, traumatic fractures, and enthesopathies, mostly on the distal parts of both arms and legs, documented in each of the adults. The compression fracture on L1 of KS-1044 is probably osteoporosis related. The brucellar vertebral lesions of KS-1042 and KS-1045 could be indicative of an involvement in the sheep and goat husbandry, which may partly explain the occupational stress, and that dairy products were part of the local diet.

The archaeological evidence suggests that those buried in Room-94 tomb were from the more prosperous section of the local ancient community as indicated by the excessive use of perfumed, suggestively expensive, substances (comp. Brun 2000, Voudouri and Tesseromatis 2015) and type of cloth used as covering shrouds (Fig. 2 A-C). Despite indications of hygienic deficiencies in the form of bad dental conditions (calculus, gingivitis, and parodontitis) and the possibly head lice related cranial porosity, no case of enamel hypoplasia was observed, not even on the child KS-1043 who apparently suffered from a lethal infection. Caries, often associated with rich carbohydrate nutrition such as dates and white bread (Roberts and Manchester 1995, Hillson 2001), was only manifested on two teeth of different individuals. The causes of 
pre-mortal tooth loss and apical abscesses, including caries, are uncertain. The documented case of gout on KS-1040 is a further indicator of rich diet and life style (Rothschild and Martin 2006, Kjellström 2012). The non-funerary Greek inscription "For the rest of Pholeos, son of Adion, this mosaic was done thanks to his gift" (Gatier 1998, 2019) in the centre of the adjacent Church-95's nave is indicative of the involvement of the rich locals or families in the construction of churches. It is thus very probable that those buried in Room-94 tomb had a privileged position in their community and church and therefore were allowed a burial within the Church's premises in their "private" tomb and not in the nearby "public" cemetery. Yet, a religious function for any of the buried can neither be confirmed nor excluded. The ancient community was very probably patrilineal, as indicated by the funerary epitaphs (comp. Gatier 1998). Hence, the buried males in Room-94 tomb possibly represented different generations of one family. They were consecutively buried, most probably during the $7^{\text {th }}$ century AD. They probably started with Individual V and VI of the least preserved skeletons KS-1041 and KS-1045, and concluded with Individual II, the best preserved and the more whitish KS-1042 skeleton. The female buried in Church-79 could be related to those in Room-94 tomb, which is not unusual in small communities. This woman was not the archaeologically anticipated burial of a male church "servant" or "functionary" (Humbert 1993). The suggested relationship of the buried with the church might have influenced the observed gender separation in the two church tombs, given that such a distinction was not observed in more than 50 excavated tombs in the nearby ancient cemetery containing multiple adult burials. Also, the position of males and females tombs along the southern and northern church walls respectively might have been religiously motivated or simply random.

Conflicts of interest: authors declare no conflict of interest

\section{Acknowledgement}

The authors are very thankful to Prof. Dr. Günter Bräuer (University Hamburg, Germany), Dr. S. Arps (Hamburg, Germany), and Garrard Cole (University College London, UK) for their technical advice, Dr. Albert Zink (director of the Eurac Research Institute for Mummy Studies in Bolzano, Italy) to provide a DNA analyses in his laboratory, Angelika Kroll (University Hamburg, Germany) for assisting in the graphics, Dr. A. Soltysiak (University of Warsaw, Poland) for his comments, and Dr Birgit Großkopf (University Göttingen, Germany) for her comments and correcting remarks. 


\section{References}

Addison C. G. 1838. Damascus and Palmyra. A journey to the East. Vol. 2, E. L. Careg and A. Hart, Philadelphia, USA.

Adler R. A. 2011. Osteoporosis in men: insights for the clinician. Therapeutic Advances in Musculoskeletal Disease 3: 191-200.

Al Qahtani S. J., Hector M. P., Liversidge H.M. 2010. Brief communication: the London atlas of human tooth development and eruption. American Journal of Physical Anthropology 142: 481-490.

Altenburger M. Y. 2009. Differential diagnostische aspekte bei der Bildgebung von Foramen jugulare Tumoren, $\mathrm{Ph}$ D thesis, Eberhard-Karls-Universität zu Tübingen, Germany.

Anastopoulou I., Zorba E., Eliopoulos C., Moraitis K. 2017.Skeletal evidence of brucellosis in a medicolegal context: A report of two cases. Romanian Journal of Legal Medicine 25:70-74.

Anjaneyulu K., Philips C., Tamang B. K., Kumar A. 2014. Patterns of talar articulating facets in adult human calcanei from North-East India and their clinical correlation. Asian Journal of Medical Sciences 5: 89-93.

Aravecchia N., Dupras T. L., Dzierzbicka D., Williams L. 2015. The church at Amheida (ancient Trimithis) in the Dakhleh Oasis, Egypt. A bioarchaeological perspective on an early Christian mortuary complex. Bioarchaeology of the Near East. 9: 21-43.

Ariza J., Bosilkovski M., Cascio. A, Colmenero J. D., Corbel M. J., Falgas M. E., Memish Z. A., Roushan M. R. H., Rubenstein E., Sipsas N. V., Solera J., Young E. J., Pappa G. 2007. Perspectives for the Treatment of Brucellosis in the 21st Century: The Ioannina Recommendations The Policy Forum allows health policy makers around the world to discuss challenges and opportunities for improving health care in their societies. PLoS Medicine 4: 1872 - 8.

DOI: https://doi.org/10.1371/journal.pmed.0040317

Aufderheide A. C. and Rodríguez-Martín C.1998. The Cambridge Encyclopedia of Human Paleopathology, 2nd ed. Cambridge University Press, Cambridge, GB.

Aydinlioğlu A., Kavakli A., Yesilyurt H., Erdem S. 2001. Foramen transversarium bipartita. Van Tip Dergisi 8: 110 - 112.

Berry A. C and Berry R. J.1967. Epigenetic variation in the human cranium. Journal of Anatomy 101: 361 - 379.

Berry A. C. 1975. Factors affecting the incidence of non-metrical skeletal variants. Journal of Anatomy 120: 519 - 535.

Bouaziz M. C., Ladeb M. F., Chakroun M., Chaabane S. 2007. Spinal brucellosis: a review. Skeletal Radiology 37: 785 - 790.

Bräuer G. 1988. Anthropometrie. In Anthropologie, Vol. I-1, R. Knußmanned., Gustav Fischer Verlag, Stuttgart, Germany, pp.160-285.

Brossman J., Czerny C., Freyschmidt J. 2001. Freyschmidt's „Köhler/Zimmer“ Grenzen des normalen und Anfänge des pathologischen in der Radiologie des kindlichen und erwachsenen Skeletts. $14^{\text {th }}$ ed., G. ThiemeVerlag, Stuttgart, Germany.

Brun J.-P. 2000. The Production of perfumes in antiquity: The cases of Delos and Paestum. American Journal of Archaeology 104: 277 - 308. 
Buikstra J. E. 2010. Paleopathology: a Contemporary Perspective. In A companion to biological anthropology, C. S. Larsen ed., Blackwell Publishing, UK, pp. 395411.

Bunning P. S. C. 1964. Some observations on the West African calcaneus and the associated talocalcaneus interosseous ligamentous apparatus. American Journal of Physical Anthropology 22: 467 - 472.

Burrell C. L. 2018. Skeletal variation as a possible reflection of relatedness within three Medieval British populations, $\mathrm{PhD}$ thesis, Liverpool John Moores University, UK.

Cai T., Yang L., Cai W., Guo S., Yu P., Li J., Hu X., Yan M., Shao Q., Jin Y., Sun Z. S., Luo Z-J. 2015. Dysplastic spondylolysis is caused by mutations in the diastrophic dysplasia sulphate transporter gene, PNAS 112: 8064 - 8069.

Caldemeyer K. S., Mathews V. P., Azzarelli B., Smith R. R. 1997. The jugular foramen: A review of anatomy, masses, and imaging characteristics. Radiographics 17: 1123 - 1139.

Capasso L. 1999. Brucellosis at Herculaneum (79 AD). International Journal of Osteoarchaeology 9: $277-288$.

Capasso L. 2007. Infectious diseases and eating habits at Herculaneum (1st century AD, southern Italy). International Journal of Osteoarchaeology 17: 350 - 357.

Cole G. 2017. Private communication.

Cole G. and Waldron T. 2016. Purple staining of archaeological human bone: an investigation of probable cause and implications for other tissues and artefacts. Journal of Anthropology, DOI: http://dx.doi.org/10.1155/2016/9479051.

Colmenero J. D., Ruiz-Mesa J. D., Plata A., Bermudez P., Martín-Rico P., QueipoOrtuño M., Reguera J. M. 2008. Clinical findings, therapeutic approach, and outcome of brucellar vertebral osteomyelitis. Clinical Infectious Disease 46: 426 $-433$.

Constas N. 2006. Death and dying in Byzantium. In Byzantine Christianity, D. Krueger ed., Fortress Press, MN, USA, pp.124-136.

Curate F. 2006. Two possible cases of brucellosis from a Clarist monastery in Alcácer do Sal, Southern Portugal. International Journal of Osteoarcheology 16: 453458.

D’Anastasio G., Staniscia, T., Milia M. L., Manzoli L., Capasso L. 2011. Origin, evolution and paleoepidemiology of brucellosis. Epidemiology and Infection 139: 149 - 156.

Dabney J., Knapp M., Glocke I., Gansauge M-T., Weihmann A., Nickel B., Valdiosera C.,García N., Pääbo S., Arsuaga J-L., Meyer, M. 2013. Complete mitochondrial genome sequence of a Middle Pleistocene cave bear reconstructed from ultrashort DNA fragments. Proceedings of the National Academy of Sciences USA 110: 15758 - 15763.

Damgaard P. B., Margaryan A., Schroeder H., Orlando L., Willerslev E., Allentoft M. E. 2015. Improving access to endogenous DNA in ancient bones and teeth. Scientific reports 5: 11184, DOI: 10.1038/srep11184.

De Vasconcellos H. A., Holanda Cavalcante M. L.T., Parreira Fortes M. M., Neves P. P., Kopke Rocha A. C. 2013. "OsTrigonum" y "Proceso de Stieda" en el syndrome del impacto posterior del Tobillo. International Journal of Morphology 31:1223-1226. 
Eerkens J. W., Nichols R. V., Murray G. G. R., Perez K., Murga E., Kaijankoski P., Rosenthal J. S., Engbring L., Shapiro B. 2018. A probable prehistoric case of meningococcal disease from San Francisco Bay: Next generation sequencing of Neisseria meningitidis from dental calculus and osteological evidence. International Journal of Paleopathology 22: 173 - 180.

Exteberria F.1994. Vertebral epiphysitis: early signs of brucellar disease. Journal of Pathology 1: 41 - 49.

Fennigan M. 1978. Non-metric variation of the infracranial skeleton. Journal of Anatomy 125:23-37.

Fletcher D. M., Unni K. K., Mertens F. 2002. WHO Classification of tumours: Pathology and genetics of tumours of soft tissue and bone. IARC Press, Lyon, France.

Francis S. and Co. 1847. Voyage round the world of the United States ships Columbia and John Adam. S. Frances \& Co., NY, J. H. Frances, Washington St., USA, p: 225.

Gatier P-L. 1998. Les inscriptions greques et latines de Samra et de Rihab. In Fouilles de Khirbet Es-Samra Jordanie, Vol. I.J.-B. Humbert, A. Desreumaux eds., CNRS , Brepols publishers, Turnhout, Belgium, pp. 359-431.

Gatier P-L. 2019. Private communication, July 2019.

Geyik M. F., Gür A., Nas K., Çevik R., Saraç J., Dikici B.; Ayaz C. 2002. Musculoskeletal involvement in brucellosis in different age groups: a study of 195 cases. Swiss Medical Weekly 132: 98 - 105.

Gokhale Y. A., Ambardekar A. G., Bhasin A., Patil M., Tillu A., Kamath J. 2003. Brucella spondylitis and sacroiliitis in the general population in Mumbai. Journal of The Association of Physicians of India . 51: 659 - 666.

Goldfus H. 2006. Burials in ordinary churches and monastic complexes of Byzantine Palestine - A synthesis. In Akten des XIV. Internationalen Kongresses für christliche Archaologie, R. Harreither, P. Pergola, P. Pillinger; A. Pülzeds., Osterreichischeakademie der wissenschaften, Wien, pp.411-418.

Graefen A. 2009. Development of a multiplex PCR for the assessment of ancient DNA preservation levels in prehistoric human remains. Magisterarbeit, Johannes Gutenberg Universität Mainz, Mainz, Germany.

Guler S.; Kokoglu O. F., Ucmak H., Gul M., Ozden S., Ozkan F. 2014. Human brucellosis in Turkey: different clinical presentations. Journal of Infection in Developing Countries 8: 581 - 588.

Hauser G. and De Stefano G. F. 1989. Epigenetic variants of the human skull. Schweizerbart Verlag, Stuttgart, Germany.

Hillson S. 2001. Recording dental caries in archaeological human remains. International Journal of Osteoarchaeology 11: 249 - 289.

Hofreiter M., Paijmans J. L. A., Goodchild H., Speller C. F., Barlow A., Fortes G.G., Thomas J. A., Ludwig A., Collins M. J. 2015. The future of ancient DNA: Technical advances and conceptual shifts. Bioessays 37: $284-293$.

Humbert J.-B. 1987. Khirbet Es Samra. Liber Annuus 37: 406 - 409.

Humbert J.-B. 1993. Le cimetière de Kh. es-Samra et quelques données démographique. Liber Annuus 39: 542 - 454. 
Humbert J.-B. 1998. Présentation du Site. Thèmes et limites de la recherché. In Fouilles de Khirbet Es-Samra Jordanie, Vol. I. J.-B. Humbert, A. Desreumaux eds., CNRS, Brepols publishers, Turnhout, Belgium, pp. 27 - 62.

Humbert J.-B 2010. La fouille de Khirbet es-Samra (Jordanie). École biblique et archéologique française de Jérusalem, (Jerusalem).

Hyer C. F., Dawson J.M., Philbin T. M., Berlet G. C., Lee T.H. 2005. The peroneal tubercle: description, classification, and relevance to peroneus longus tendon pathology. Foot and Ankle International 26: 947 - 950.

Jaffe H. L. 1958. Tumours and tumorous conditions of the bones and joints, Lea and Febiger Philadelphia, USA.

Kazhdan A. P., Talbot, M-A., Cutler A., Gregory E. T., Ševčenko, N. P. 1991. Cemetery. In The Oxford Dictionary of Byzantium, Vol. 1, Oxford University Press, UK, pp. 396.

Khalil L. 1998. University of Jordan excavation at Khirbet Yajuz, Annual of the Department of Antiquities of Jordan 42: 456 - 467.

Khurana J., Abdul-Karim F., Bovée J.V.M.G. 2002. Osteochondroma. InWHO Classification of Tumours. Pathology and Genetics of Tumours of Soft Tissue and Bone. C. D.M. Fletcher, K. K. Unni, F. Mertens eds., IARC Press, Lyon, France, pp. 234 - 235.

Kim M. W., Lim S. T., Sohn M. H. 2003. Unusual findings of benign enchondroma in the ulna on 3-phase bone scintigraphy. Clinical Nuclear Medicine 28: 778 779 .

Kirsanow K. and Burger J. 2012. Ancient Human DNA. Annals of Anatomy 194:121132.

Kjellström A. 2012. Possible cases of leprosy and tuberculosis in medieval Sigtuna, Sweden. International Journal of Osteoarchaeology 22: 261 - 283.

Leone A., Cianfoni A., Cerase A., Magarelli N., BonomoL. 2011. Lumbar spondylolysis: a review. Skeletal Radiology 40: 683 - 700.

Lifeso R. M., Harder E., Mccorkell S. J. 1985. Spinal brucellosis. British Journal of Bone Joint Surgeon 67: 345 - 351.

Lovejoy O. 1985. Dental wear in the Libben population: its functional pattern and role in the determination of adult skeletal age at death. American Journal of Physical Anthropology 68: 47 - 56.

Lukacs J. R. and Martin C. R. 2002. Lingual cortical mandibular defects (Stafne's Defect): An anthropological approach based on prehistoric skeletons from the Canary Islands. International Journal of Osteoarchaeology 12:112 - 126.

Margalit S. 1990.The bi-apsidal churches in Palestine, Jordan, Syria, Lebanon, and Cyprus. Liber Annuus 40: 321 - 334, plate 45-48.

Mays S. A. 2007. Lysis at the anterior vertebral body margin: evidence for brucellar spondylitis? International Journal of Osteoarchaeology 17: 107 - 118.

Mcgongle D., Tan A. L., Grainger A. J., Benjamin M. 2008. Heberden's nodes and what Heberden could not see: the pivotal role of ligaments in the pathogenesis of early nodal osteoarthritisand beyond. Rheumatology 47: 1278 - 1285.

Minozzi S., Bianchi F., Pantano W., Catalano P., Caramella D., Fornaciari G. 2013. A case of gout from Imperial Rome (1st-2nd Century AD). Clinical Research and Bioethics, DOI: http://dx.doi.org/10.4172/2155-9627.1000162.

Mishra G. P., Bhatnagar S., Singh B., Mishra P. P., Mishra A. 2014. Anatomical variations in foramen transversarium of typical cervical vertebrae and clinical significance. International Journal of Biomedical Research 5: 405 - 407. 
Mohammadi A., Asl A. H., Ghasemi-Rad M., Noroozinia F. 2012. Enchondroma protuberans of ulnar bone: A case report and review of literature. Case Reports in Radiology. $\quad$ DOI: 10.1155/2012/278920.

Nabulsi A.J. 1998. The Byzantine Cemetery in Khirbet Es-Samra. In Fouilles de Khirbet Es-Samra Jordanie, Vol. I. J.-B. Humbert, A. Desreumaux eds., CNRS , Brepols publishers, Turnhout, Belgium, pp. 271-279.

Nabulsi A. J. 2011. Human burials from the Baptism Site Project. Annual of the Department of Antiquities of Jordan 55: 33 - 42.

Nabulsi, A. J., Abu-Shmeis A., Eger C. 2007. The ancient cemetery in Khirbet es-Samrā after the sixth season of excavation. Annual of the Department of Antiquities of Jordan 51: 273 - 281.

Nabulsi A. J., Abbadi A., Shami A., Askar H. 2009. Khirbet es-Samrā ancient cemetery: Outline of Site C. Annual of the Department of Antiquities of Jordan 53: 167 172.

Ortner D. J. 2003. Identification of Pathological Conditions in Human Skeletal Remains. 2nd ed., Academic Press, San Diego, USA.

Parker S. T. 1999. An Empire's New Holy Land: The Byzantine Period. Near Eastern Archaeology 62: 134 - 180.

Pérez I. E., Chávez A. K., Ponce D. 2014. Frequency of ponticulusposticus in lateral cephalometric radiography of Peruvian patients. International Journal of Morphology 32: 54 - 60.

Piccirello M. 1989. Recentiscoperte di archeologiacristiana in Giordania. InActes du XIe congrès international d'archéologie chrétienne. École Française de Rome, Rome, Italy, pp. 1697-1735.

Piccirello M. 1991. Il complesso di santo Stefano a Umm al-Rasas-Kastron Mefaa in Giordania (1986-1991). Liber Annuus 41: 327 - 364.

Politis K. D. 2010. The monastery of Aghios Lot at Deir 'Ain 'Abata in Jordan. In Byzanz - das Römerreich im Mittelalter, Vol. 1, F. Daimand J. Drauschkeeds., Schnell and Steiner Verlag, Germany, pp.1-24.

Radi S., Karaplis A. C. 2017. A Case of male osteoporosis: a 37 year old man with multiple vertebral compression fractures. Case Reports in Endocrinology 2017: 1-7. DOI: https://doi.org/10.1155/2017/6328524.

Ramosaço E., Kolovani E., Rroji A., Kraja D. 2017. Cervical brucellosis, with or without bone injury. International Conference on Innovations in Science and Education, Prague 2017, pp. 1013-1017.

Rashidi J. S, Ortner D. J., Frohlich B., Jonsdottir B. 2001. Brucellosis in Early Bronze Age Jordan and Bahrain: an analysis of possible cases of Brucella Spondylitits. American Journal of Physical Anthropology Supplement 32: 122 - 123.

Reddy V. K. 2015. Os Trigonum syndrome - A case report. International Journal of Biomedical and Advance Research 6: 60 - 63.

Rizzi E., Lari M., Gigli E., De Bells G., Caramelli D. 2012. Ancient DNA studies: new perspectives on old samples. Genetics Selection Evolution 44:21, DOI:10.1186/1297-9686-44-21.

Roberts C., Manchester K. 1995. The Archaeology of Disease, 2nd ed., Ithaca, New York.

Rohland N., Siedel H., Hofreiter M. 2010. A rapid column-based ancient DNA extraction method for increased sample throughput. Molecular Ecology Resources 10: 677 - 683. 
Rösing F. W. 1981. Discreta des menschlichen Skeletts- ein kritische Überblick. Homo 33: $100-125$.

Rösing F. W. 1988. Körperhöhenrekonstruktion aus Skelettmaßen. Diagnistik. In Anthropologie, Vol. I-1, R. Knußmanned., Gustav Fischer Verlag, Stuttgart, Germany, pp. 586-600.

Rotes-Querol J. 1957. Osteo-articular sites of brucellosis. Annuals of Rheumatic Diseases 16: 63 - 68.

Rothschild B. M., Martin L. R. 2006. Skeletal impact of disease. New Mexico Museum of Natural History and Science, Bulletin 33, Albuquerque, U.S.A.

Sakai T., Sairyo K., Suzue N., Kosaka H., YasuiN. 2010. Incidence and etiology of lumbar spondylolysis: review of the literature. Journal of Orthopaedic Science 15: $281-288$.

Schick R. 1995. Christianity at Humayma, Jordan. Liber Annuus 45: 319 - 342.

Schultz M. 1988. Paläopathologische Diagnistik. In Anthropologie, Vol. I-1, R. Knußmanned., Gustav Fischer Verlag, Stuttgart, Germany, pp:480-496.

Sidlauskas K. M., Sutton E. E., Biddle M. A. 2014. Osteoporosis in men: epidemiology and treatment with denosumab. Clinical Interventions in Aging 9: 593 - 601.

Singer A. 1995. Palestinian peasants and Ottoman officials. Cambridge studies in Islamic civilization, Cambridge University Press, Cambridge, UK, p:114.

Sjøvold T., 1988. Geschlechtsdiagnose am Skelett. In Anthropologie, Vol. I-1, R. Knußmanned., Gustav Fischer Verlag, Stuttgart, Germany, pp:444-480.

Slavec Z. Z. 2005. Identification of family relationships by epigenetic traits. Anthropologischer Anzeiger 63: 401 - 408.

Solera J., Lozano E., Martinez-Alfaro E., Espinosa A., Castillejos M.L., Abad L. 1999. Brucellar spondylitis: review of 35 cases and literature survey. Clinical Infectious Disease 29: 1440 - 1449.

Standaert C. J. and Herring S. A. 2000. Spondylolysis: a critical review. British Journal of Sports and Medicine 34:415-422.

Stanghellini I., Bertorelli R., Capone L., Mazza V., Neri C., Percesepe A., Forabosco A. 2006. Quantitation of fetal DNA in maternal serum during the first trimester of pregnancy by the use of a DAZ repetitive probe. Molecular Human Reproduction 12: 587 - 591.

Stini W. A. 1990. Osteoporosis: Etiologies, prevention, and treatment. Yearbook of Physical Anthropology 33: 151 - 194.

Sullivan K. M., Mannucci A., Kimpton C. P., Gill P. 1993. A rapid and quantitative DNA sex test - fluorescence-based PCR analysis of X-Y homologous gene amelogenin. Biotechniques 15: 637 - 641.

Szilvássy J., 1988. Altersdiagnose am Skelett. In Anthropologie, Vol. I-1, R. Knußmanned., Gustav Fischer Verlag, Stuttgart, Germany, pp: 421-443.

Teegen W.-R., Schultz M. 1999. Symphalangism of the fifth toe in the early medieval Slavic population from Starigard/Oldenburg (Northern Germany). Homo 50: 244 $-248$.

Tekkök I. H., Berker M., Özcan O. E., Özgen T., Akalin E. 1993. Brucellosis of the spine. Neurosurgery 33: $838-844$.

Thomas J. P., Berner R., Zahnert T., Dazert S. 2014. Acute otitis media: a structured approach. Deutsches Ärzteblatt International 11: 151 - 160. 
Thomasius F., Baum E., Bernecker P., Bäcker W., Brabant T., Clarenz P., Demary W., Dimai H., Engelbrecht M., Engelke K., Fratermann U., Grieser T., Gulich M.,, Hadji P., Henning J., Jehle P., Kern, P., Ketteler M., Klatt G., Kurth A. 2018. DVO Leitlinie 2017 zur Prophylaxe, Diagnostik und Therapie der Osteoporose bei postmenopausalen Frauen und Männern: Kurzversion. Osteologie 27: 154 160.

Tritsaroli P., Valentin F. 2008. Byzantine burials practices for children; case studies based on a bioarchaeological approach to cemeteries from Greece. In Nasciturus, Infans, Puerulus Vobis Mater Terra: La Muerte en la Infancia, F.G. Jener ,S. Muriel, C. Olária eds., Diputació de Castelló, Serveid' Investigacions Arqueològiquesi Prehistòriques. Spain, pp : 93-113.

Ullinger J. M. 2010. Skeletal health changes and increasing sedentism at Early Bronze Age Bab edh-Dhra, Jordan, PhD Thesis, Ohio State University, USA.

Veleminsky P. and Dobisiková M. 2005. Morphological likeness of the skeletal remains in a central European family from 17th to 19th century. Homo 56: $173-196$.

Vogl T. J. and Bisdas S. 2009. Differential diagnosis of jugular foramen lesions. Skull Base 19: 3 - 16.

Voudouri D. and Tesseromatis C. 2015. Perfumery from myth to antiquity, International Journal of Medicine and Pharmacy 3: 41 - 55.

Waldrun T. 2009. Palaeopathology. Cambridge University Press, Cambridge, UK.

Yadav Y., Goswami P., Bharihoke V. 2014. An osteological study of foramen trasversarium: variations and clinical aspects. Journal of Evolution of Medicine and Dental Science 3: 14562 - 14566.

Yang X., Meng X., Shi W., Du Y., Zhang L., Wang Y. 2014. The comparison of the manifestation of the clinical imageology and pathology between the brucellar spondylitis and the spine tuberculosis. Surgical Science 5: 60 - 69.

Young K. J., Koning W. 2003. Spondylolysis of L2 in identical twins. Journal of Manipulative and Physiological Therapeutic 26: 196 - 201.

Zaki M. E., Hussien F. H., El Banna R. D. 2009. Osteoporosis among ancient Egyptians. International Journal of Osteoarchaeology 19: 78 - 89.

Zayadine F. 1985. Jordanie. In Chronique archéologique. A. Olivier, Syria 62: 125-169.

To cite this article:

Nabulsi A.J., Schönrock-Nabulsi P., Humbert J-B., Desreumaux A., Wurst C. 2020. Intramural Burials from the Ancient Byzantine Settlement in Khirbet es-Samrā in Jordan.

International Journal of Modern Anthropology. 2 (14): 237 - 273

DOI: http://dx.doi.org/10.4314/ijma.v2i14.2

\section{(@) $\mathbb{Q \Theta \Theta}$}

This article, as all articles published in this journal, is under The Creative Commons Attribution: Attribution-NonCommercial-NoDerivatives 4.0 International (CC BY-NC-ND 4.0). https://creativecommons.org/licenses/by-nc-nd/4.0/ 